\title{
Article \\ Mechanical and Thermo-Physical Performances of Gypsum-Based PCM Composite Materials Reinforced with Carbon Fiber
}

\author{
Bo Zhang ${ }^{1}$, Haibin Yang ${ }^{1,2}$, Tao $\mathrm{Xu}^{3}$, Waiching Tang ${ }^{4}\left(\mathbb{D}\right.$ and Hongzhi Cui ${ }^{1, *}$ \\ 1 College of Civil and Transportation Engineering, Shenzhen University, Shenzhen 518060, China; \\ 2172332351@email.szu.edu.cn (B.Z.); hbyang3-c@my.cityu.edu.hk (H.Y.) \\ 2 Department of Architecture and Civil Engineering, City University of Hong Kong, Hong Kong, China \\ 3 School of Civil Engineering, Guangzhou University, Guangzhou 510006, China; beexu@gzhu.edu.cn \\ 4 School of Architecture and Built Environment, The University of Newcastle, Callaghan, NSW 2308, Australia; \\ patrick.tang@newcastle.edu.au \\ * Correspondence: h.z.cui@szu.edu.cn; Tel.: +86-755-26537849
}

Featured Application: Building energy storage wall.

Citation: Zhang, B.; Yang, H.; Xu, T.; Tang, W.; Cui, H. Mechanical and Thermo-Physical Performances of Gypsum-Based PCM Composite Materials Reinforced with Carbon Fiber. Appl. Sci. 2021, 11, 468. https://doi.org/10.3390/app11020468

Received: 3 December 2020

Accepted: 28 December 2020

Published: 6 January 2021

Publisher's Note: MDPI stays neutral with regard to jurisdictional clai$\mathrm{ms}$ in published maps and institutional affiliations.

Copyright: () 2021 by the authors. Licensee MDPI, Basel, Switzerland. This article is an open access article distributed under the terms and conditions of the Creative Commons Attribution (CC BY) license (https:// creativecommons.org/licenses/by/ $4.0 /)$.

\begin{abstract}
Phase change materials (PCMs) have received extensive attention due to their high latent heat storage density and isothermal behavior during heat charging and discharging processes. The application of PCMs in buildings would match energy supply and demand by using solar energy effectively, thereby reducing building energy consumption. In this study, a diatomite/paraffin (DP) composite was prepared through a vacuum-impregnated process. The thermo-physical performance, thermal stability, chemical structure and thermal reliability of the DP composite were evaluated. To develop a structural-functional integrated energy storage building material, carbon fibers (CF) were chosen as the reinforcing material. The mechanical and thermal properties of CF-reinforced $\mathrm{DP} /$ gypsum were examined. It is evident that the flexural strength and thermal conductivity of DP/gypsum containing $1 \mathrm{wt}$. \% CF increased by $176.0 \%$ and $20.3 \%$, respectively. In addition, the results of room model testing demonstrated that the presence of CF could enhance the overall thermal conductivity and improve the thermo-regulated performance of DP/gypsum. Moreover, the payback period of applying CF-reinforced DP/gypsum in residential buildings is approximately 23.31 years, which is much less than the average life span of buildings. Overall, the CF reinforced $\mathrm{DP} /$ gypsum composite is promising for thermal energy storage applications.
\end{abstract}

Keywords: phase change material; diatomite/paraffin composite; carbon fiber; thermal conductivity; mechanical properties; feasibility analysis

\section{Introduction}

In recent years, the global issues of excessive energy consumption and high greenhouse gas emissions have threatened the human living environment [1-3]. The energy consumption of the construction sector (residential and commercial) currently accounts for more than $30 \%$ of total global energy consumption, and this figure is up to $40 \%$ in developed countries [4]. At the same time, the increasing demand for energy used in the cooling and heating of residential and commercial buildings to maintain human comfort has hugely impacted natural resources and the environment. As such, improving the energy efficiency in buildings is crucial to solving the problems.

Solar energy is the most important source of renewable energy available today. Different technologies such as solar photovoltaic systems have been developed to apply solar energy in buildings to ease the current shortage of energy, but their efficiency is not satisfactory. Phase change materials (PCM), having a high latent heat energy storage and isothermal behavior during heat charging and discharging processes, can be 
used as thermal energy storage materials in buildings to reduce temperature variations, as well as to regulate the indoor temperature to coincide with the human comfort zone $\left(20-28^{\circ} \mathrm{C}\right)[5,6]$. Apparently, incorporating PCM into gypsum [7] or the cement-based building elements [8-11] is a simple and effective way to improve the energy efficiency of buildings.

Paraffins are the most studied PCMs for building applications because they have several advantages, such as being non-corrosive and non-supercooling, and having high latent heat, small volume changes in phase change process and good thermal stability [1,12]. They are also available over a wide range of phase change temperatures, ranging from approximately $20^{\circ} \mathrm{C}$ up to $70{ }^{\circ} \mathrm{C}$. However, they cannot be incorporated directly into building elements because leakage may occur during phase transition process [13]. Therefore, several incorporation techniques, such as shape-stabilized PCM (SSPCM), have been developed to address the leakage issue. Porous materials, such as diatomite [14], expanded graphite [15], porous aggregate [16-18] and kaolin [19], as well as synthetic porous materials [20-22], are often chosen as the supporting materials to store PCM. In particular, diatomite is a promising carrier because of its high storage capacity, special pores structure, light weight, thermo-stability property and chemical inertness [23,24]. Rao et al. [25] reported that the adsorptive capacity of diatomite could reach up to $47 \%$, and the thermal properties of the diatomite/magnesium nitrate hexahydrate composite remained stable after 2000 cooling/heating cycles. Besides this, Konuklu et al. [26] stated that the thermal stability of diatomite/paraffin (DP) remained stable up to $95^{\circ} \mathrm{C}$, and no paraffin leakage was observed because of the high capillary force of diatomite. So, diatomite/PCM is appropriate to use as a thermal energy storage material in buildings.

Nevertheless, it is worth noting that diatomite belongs to the group of pozzolanic materials with high amorphous silica contents $[24,27,28]$, which can react with the portlandite in cement to generate calcium silicate hydrates (C-S-H). If DP is mixed with cement-based materials directly without covering $[29,30]$, the pozzolanic reaction between diatomite and cement would destroy the porous structure of diatomite, and consequently leakage of PCM would happen. However, most studies using DP in cement-based materials did not consider or recognize this problem. To utilize DP successfully in buildings, suitable bulk building materials as alternative matrix materials must be sought.

Gypsum is a versatile building material used in partitions, interior walls, soil [31], and decoration [32]. More importantly, gypsum and diatomite are compatible. So, an energy storage building material can be developed by incorporating DP into gypsum. However, the low thermal conductivity of gypsum $(0.5 \mathrm{~W} /(\mathrm{m} \cdot \mathrm{K}))$ would inevitably restrict the heat transfer efficiency of PCM. Besides this, the interface between DP and the gypsum matrix is considered the weak link in gypsum with respect to durability and strength. To solve these problems, carbon-based materials with high thermal conductivity, such as expanded graphite (EG) [33], carbon nanotubes (CNT) [34] and graphite [35], have been used to improve the thermal conductivity as well as the thermal performance of gypsum-based DP composites. Tang et al. [33] stated that the thermal conductivity of diatomite/fatty acid eutectics increased by $26.3 \%$ and $53.7 \%$ after adding $3 \%$ and $5 \%$ EG, respectively. The small addition of carbon materials is enough to raise the thermal conductivity to a desired level. On the other hand, the excellent tensile strength of carbon fiber could restrain the cracks' growth and contribute to the improvement in the flexural strength of the cementitious materials. Cui et al. [36] reported that $1 \mathrm{wt}$. \% CF could significantly improve the 28-day flexural strength of cement paste and alkali-activated slag paste by $130.8 \%$ and $302.6 \%$, respectively.

The purpose of this study is to develop a kind of structural-functional integrated energy storage building material, which could have a good thermo-regulated performance and high mechanical properties. CF was innovatively used as the reinforcing material for improving the mechanical and thermo-regulated properties of the DP/gypsum system. An analysis of the feasibility of applying the DP/gypsum composite in buildings in terms of economic, practical, and environmental aspects was carried out. The results of this study 
can contribute to filling the knowledge gap pertaining to the design and preparation of a structural-functional integrated gypsum-based building material.

\section{Materials and Methods}

\subsection{Materials}

The characteristics and appearances of the main materials used in this study are shown in Table 1. Paraffin (25\#) was purchased from Sinopec Group. Its melting temperature and latent heat were approximately $22^{\circ} \mathrm{C}$ and $120 \mathrm{~J} / \mathrm{g}$, respectively. The gypsum (SZ-GY2000) with an initial setting time of 8-10 min was purchased from Bosheng Gypsum Products Co., Ltd. in Guangzhou, China. Diatomite (SD 301\#) was purchased from Fuchen Chemical Reagent Factory in Tianjin, China. Polyacrylonitrile-based short carbon fibers (PAN-CF, $700 \mathrm{SC}-12 \mathrm{~K}$ ), with an average diameter of $7 \mu \mathrm{m}$ and length of $3 \mathrm{~mm}$, were purchased from Kaben Composite Materials Co., Ltd. in Guangzhou, China. Carboxymethyl cellulose (CMC) purchased from Macklin Inc. was used as a dispersant to disperse the $\mathrm{CF}$ in gypsum slurry.

Table 1. Characteristics of the main materials used in this study.

\begin{tabular}{|c|c|c|}
\hline Materials Name & Product No. & Physical Properties \\
\hline Paraffin & $25 \#$ & $\begin{array}{l}\text { Melting temperature: } \sim 22{ }^{\circ} \mathrm{C} \\
\text { Latent heat: } \sim 120 \mathrm{~J} / \mathrm{g}\end{array}$ \\
\hline Gypsum & SZ-GY2000 & $\begin{array}{l}\text { Setting time: } 8-10 \mathrm{~min} \\
\text { Expansion: less } 0.08 \%\end{array}$ \\
\hline Diatomite & SD 3001\# & $\begin{array}{c}\text { Bulk density: } 0.34-0.65 \mathrm{~g} / \mathrm{cm}^{3} \\
\text { Specific surface area: } 40-65 \mathrm{~m}^{2} / \mathrm{g} \\
\text { Pore volume: } 0.45-0.98 \mathrm{~m}^{3} / \mathrm{g} \\
\text { Density: } 0.47 \mathrm{~g} / \mathrm{cm}^{3}\end{array}$ \\
\hline $\mathrm{CF}$ & 700 SC-12K & $\begin{array}{l}\text { Tensile strength: } \sim 4.9 \mathrm{GPa} \\
\text { Tensile modulus: } \sim 230 \mathrm{GPa} \\
\text { Density: } 1.8 \mathrm{~g} / \mathrm{cm}^{3}\end{array}$ \\
\hline $\mathrm{CMC}$ & C804619 & Viscosity: $400-800 \mathrm{mPa} . \mathrm{s}$ \\
\hline
\end{tabular}

\subsection{Preparation of the DP Composite}

The preparation procedures of the DP composite were as follows.

First, $50 \mathrm{~g}$ diatomite and $200 \mathrm{~g}$ liquid paraffin were put into a $500 \mathrm{~mL}$ beaker and stirred for $2 \mathrm{~min}$. Then, the mixture was placed into a vacuum chamber with a pressure of less than $0.1 \mathrm{MPa}$ for two hours of impregnation time while the paraffin was kept in liquid state. Once the impregnation was completed, the excess paraffin from the DP composites was filtered out under a vacuum atmosphere. Afterwards, the DP was dried in an oven of $60^{\circ} \mathrm{C}$ and the remaining paraffin on the surface of the DP that was not absorbed by the diatomite was removed by the highly lipophilic papers. This process was repeated continuously until the paper was shown with no wet marks. Finally, the DP composite was prepared and ready for use.

\subsection{Characterization of the DP Composite}

An FESEM (field emission scanning electron microscope, SU-70, Japan) was used to observe the microstructure of diatomite and the DP composite. The magnification was up to 5700 times, and the testing voltage was $15 \mathrm{kV}$. An EDS (energy-dispersive spectrometer) was also employed to characterize the change in the chemical elements of diatomite before and after absorbing the paraffin.

A BET (Brunauer Emmett Teller, NOVA1200e, America) was used to identify the pore size distribution and the total pore volume of diatomite.

DSC (differential scanning calorimetry, DSC-200F3, America) was used to determine the melting and solidification temperatures of paraffin and the DP composite, as well as their corresponding latent heat values. The samples were heated/cooled at $2{ }^{\circ} \mathrm{C} / \mathrm{min}$ over the temperature range of $0-60{ }^{\circ} \mathrm{C}$. Besides this, the specific heat capacities of the 
diatomite/paraffin/gypsum composites were measured by DSC with the operating temperatures ranging from 0 to $60^{\circ} \mathrm{C}$. Meanwhile, the impregnation ratio of paraffin in the DP composite was calculated using the following equation:

$$
\gamma 1=\frac{\Delta H_{D P}}{\Delta H_{P C M}}
$$

where $\gamma 1$ is the impregnation ratio of paraffin in the composite. $\Delta H_{D P}$ and $\Delta H_{P C M}$ represent the measured heat enthalpy of DP and pure paraffin through DSC, respectively.

TGA (thermogravimetric analysis, TGA Q50, America) was used to evaluate the thermal stability of DP. The sample was heated at $10^{\circ} \mathrm{C} /$ min over the temperature range of $0-600{ }^{\circ} \mathrm{C}$. The mass percentage of paraffin in diatomite was computed using the formula below:

$$
\gamma 2=\frac{\Delta m_{D P}}{\Delta m_{P C M}}
$$

where $\gamma 2$ is the mass percentage of paraffin. $\Delta m_{D P}$ refers to the DP's weight expressed with unit mass $(100 \%) ; \triangle m_{P C M}$ represents the mass of paraffin.

An FT-IR (Fourier transform infrared spectrometer, Perkin Elmer Spectrum 100, America) was used to verify the chemical structures of paraffin, diatomite and the DP composite. The wavelengths used ranged from $500 \mathrm{~cm}^{-1}$ to $4000 \mathrm{~cm}^{-1}$.

A thermal cycle test (Temp \& Humi Programmable Chamber, BE-TH-150, China) was performed to assess the thermal reliability of DP. The DP was placed in a thermal cycling chamber and underwent up to 600 thermal cycles of melting and solidification. In each thermal cycle, the temperature was increased from $10{ }^{\circ} \mathrm{C}$ to $40{ }^{\circ} \mathrm{C}$ at a rate of $2{ }^{\circ} \mathrm{C} / \mathrm{min}$. Then the temperature was kept at $40^{\circ} \mathrm{C}$ for $40 \mathrm{~min}$. After that, the temperature was decreased from 40 to $10^{\circ} \mathrm{C}$ at the same rate, and finally the temperature was kept at $10{ }^{\circ} \mathrm{C}$ for $30 \mathrm{~min}$. Each thermal cycle took $190 \mathrm{~min}$ to complete. Any changes in phase change temperatures and latent heats before and after the thermal cycling tests (300 and 600 cycles) were revealed by the DSC analyses.

\subsection{The Preparation of the DP/Gypsum Composites}

Different proportions of DP and carbon fiber were used to prepare the structuralfunctional integrated gypsum-based building material. The detailed sample preparation was performed as follows: Firstly, all the materials were poured into the mixer and stirred for $2 \mathrm{~min}$ to achieve homogeneity. Then, the mixtures were poured into the three different steel molds with dimensions of $40 \mathrm{~mm} \times 40 \mathrm{~mm} \times 160 \mathrm{~mm}$ (for mechanical test), $40 \mathrm{~mm} \times 200 \mathrm{~mm} \times 200 \mathrm{~mm}$ (for room model test) and $\Phi 30 \mathrm{~mm} \times 40 \mathrm{~mm}$ (for thermal conductivity test). After $1 \mathrm{~h}$, the samples were unmolded and kept in an indoor environment $\left(20 \pm 1{ }^{\circ} \mathrm{C}\right.$ and $\left.60 \% \mathrm{RH}\right)$ for 7 days until testing. The mix proportion of DP/gypsum is shown in Table 2. G-C represents the control group, and G- $x \mathrm{x} \% \mathrm{DP}-\mathrm{x} \% \mathrm{CF}$ represents that $\mathrm{XX} \%$ diatomite/paraffin composite and $\mathrm{X} \%$ carbon fiber were added to gypsum.

Table 2. The mix proportion of diatomite/paraffin/gypsum (DP/gypsum).

\begin{tabular}{llllll}
\hline No. & Gypsum (g) & Water (g) & DP (g) & CF (g) & CMC (g) \\
\hline G-C & 3600 & 1300 & - & - & 3.6 \\
G-1\% CF & 3600 & 1300 & - & 36 & 3.6 \\
G-10\% DP & 3600 & 1300 & 360 & - & 3.6 \\
G-20\% DP & 3600 & 1300 & 720 & - & 3.6 \\
G-10\% DP-1\% CF & 3600 & 1300 & 360 & 36 & 3.6 \\
G-20\% DP-1\% CF & 3600 & 1300 & 720 & 36 & 3.6 \\
\hline
\end{tabular}




\subsection{The Characterization of the DP/Gypsum Composites}

\subsubsection{The Testing of Mechanical Strengths}

The compressive and flexural strength tests were conducted according to the requirements of the China national standard of GB/T 176167.3-1999 (Test methods of strength of gypsum). The loading rates of flexural strength and compressive strength tests were $50 \pm 10 \mathrm{~N} / \mathrm{s}$ and $2.4 \pm 0.2 \mathrm{kN} / \mathrm{s}$, respectively. Each strength result was the average of three identical samples.

\subsubsection{The Testing of Thermal Conductivity}

The thermal conductivity was measured with a thermal conductivity meter (XIAT$\mathrm{ECH}, \mathrm{TC} 3000$, China) based on the hot wire method [25]. Each value was the average of three identical samples and the standard deviation was kept less than $0.002 \mathrm{~W} /(\mathrm{m} \cdot \mathrm{K})$. The measuring temperature ranged from 19 to $21^{\circ} \mathrm{C}$.

\subsubsection{The Testing of Thermo-Regulated Performance}

The thermal-regulated performance of the gypsum-based composite with different DP and CF contents was studied using self-designed room models. Five test room samples were made, and each consisted of six panels out of which five were made up of foam boards with a thickness of $45 \mathrm{~mm}$, while the top panel was made with a gypsum-based composite. The size of the models was $290 \mathrm{~mm} \times 290 \mathrm{~mm} \times 285 \mathrm{~mm}$ with an internal dimension of $200 \mathrm{~mm} \times 200 \mathrm{~mm} \times 200 \mathrm{~mm}$ (as shown in Figure 1a,b). The dimensions of the gypsum panels were $200 \mathrm{~mm} \times 200 \mathrm{~mm} \times 40 \mathrm{~mm}$. A thermocouple (Type K resolution $\pm 0.3^{\circ} \mathrm{C}$ ) connected to a data-logger was placed in the center of the room model to record the temperature variation during the heating and cooling processes.

(a)

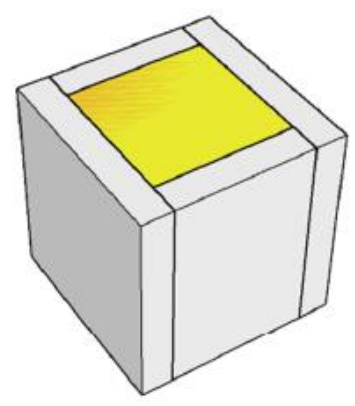

(c)

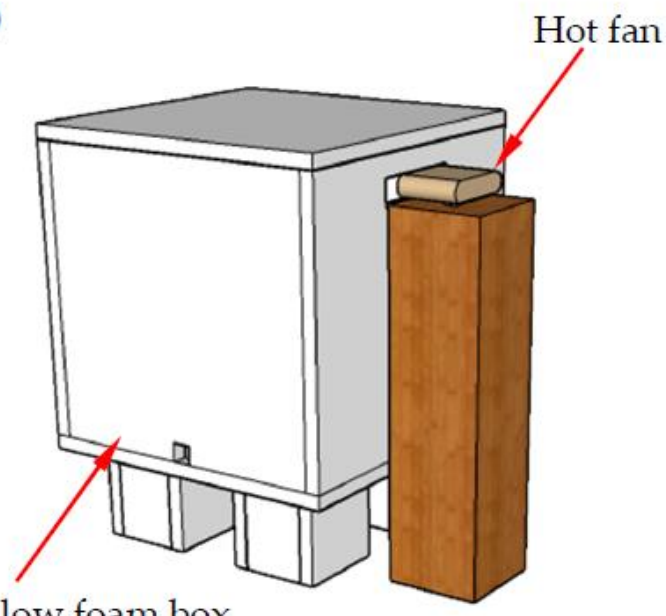

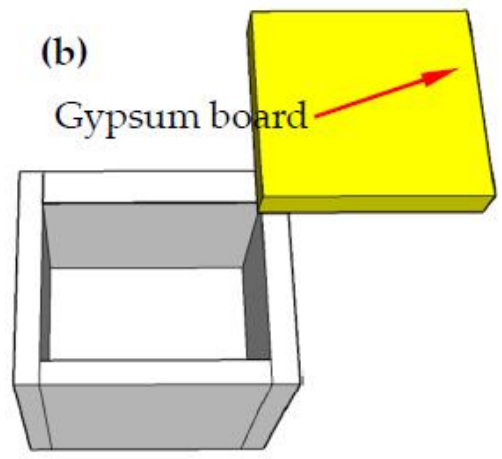

(d)

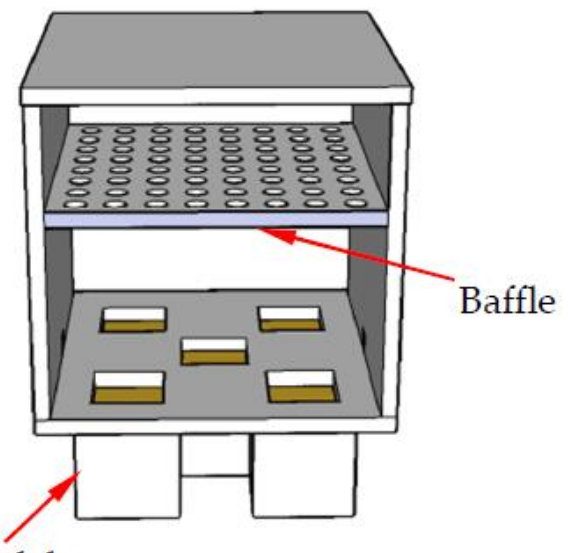

Room models

Figure 1. The schematic diagram of thermo-regulated performance testing: (a) Room model; (b) Schematic diagram of room model; (c) Testing system; (d) Section of testing system. 
A hollow foam box with dimensions of $1000 \mathrm{~mm} \times 1000 \mathrm{~mm} \times 1000 \mathrm{~mm}$ and connected with a hot fan was used to create a stable temperature environment as shown in Figure 1c,d. A baffle, consisting of 64 evenly distributed holes each with a diameter of $60 \mathrm{~mm}$ (Figure 1d), was placed at a position of $400 \mathrm{~mm}$ below the top of the foam to create uniform heat flow. Five identical square openings with sizes of $200 \mathrm{~mm} \times 200 \mathrm{~mm}$ at the bottom of the foam box were made, allowing the heat flow through the test panels, as shown in Figure 1d. This setup could enable the room models to be tested under the same experimental conditions. The ambient temperature was maintained at approximately $18^{\circ} \mathrm{C}$ during the test, and each room model was heated for $170 \mathrm{~min}$ by the hot fan and then cooled down for another $220 \mathrm{~min}$. The inner temperature readings of the room models were recorded and compared.

\section{Results and Discussion}

\subsection{Characterization of the DP Composite}

\subsubsection{Microstructure of the Diatomite and DP Composite}

As shown in Figure 2a, the diatomite exhibited a disc-shaped structure with many unconnected pores on its surface, while some of the pores were blocked by impurities. Figure $2 b$ shows the microscopic morphology of diatomite after adsorbing the paraffin, in which the number and size of pores were significantly reduced compared with the pure diatomite. It can be inferred that the pores were filled up by paraffin. The relative pressure (P/P0) range of $0.4-0.8$, as shown in Figure 3a, can be attributed to the capillary condensation during mesoporous adsorption, which shows that the majority of pores were mesopores [37]. Besides this, it can be seen from Figure $3 b$ that the pore size of diatomite was generally below $220 \mathrm{~nm}$, and the macropores (larger than $50 \mathrm{~nm})$, mesopores $(2-50 \mathrm{~nm}$ ) and micropores occupied $17.26 \%, 48.66 \%$ and $34.08 \%$ of the total volume, respectively. Due to the significant amounts of mesopores and micropores, it can be stated that the absorption capacity of diatomite is high enough to store paraffin, as these pore structures have a high surface tension and capillary force.
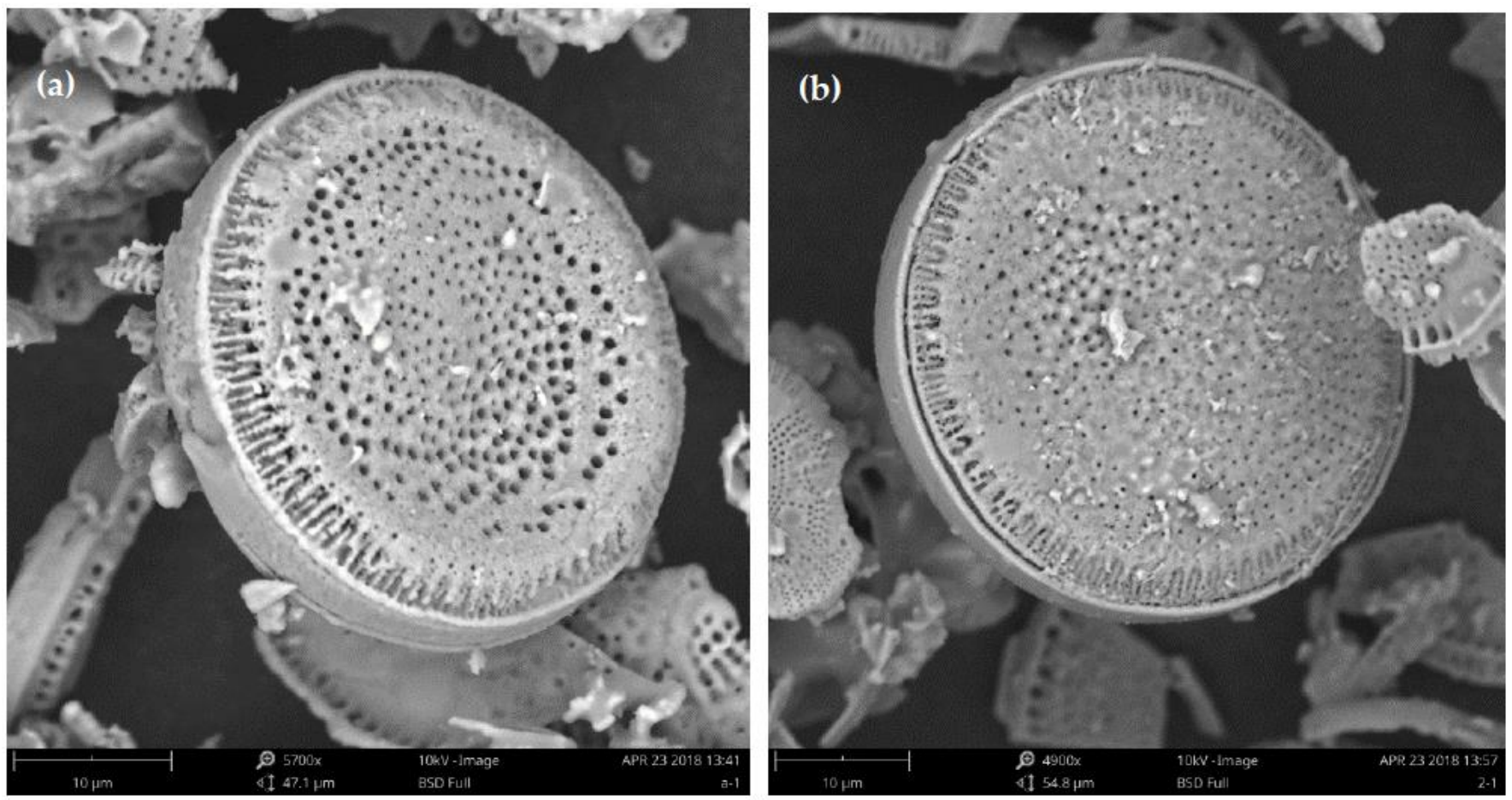

Figure 2. SEM images of (a) diatomite, and (b) diatomite/paraffin. 


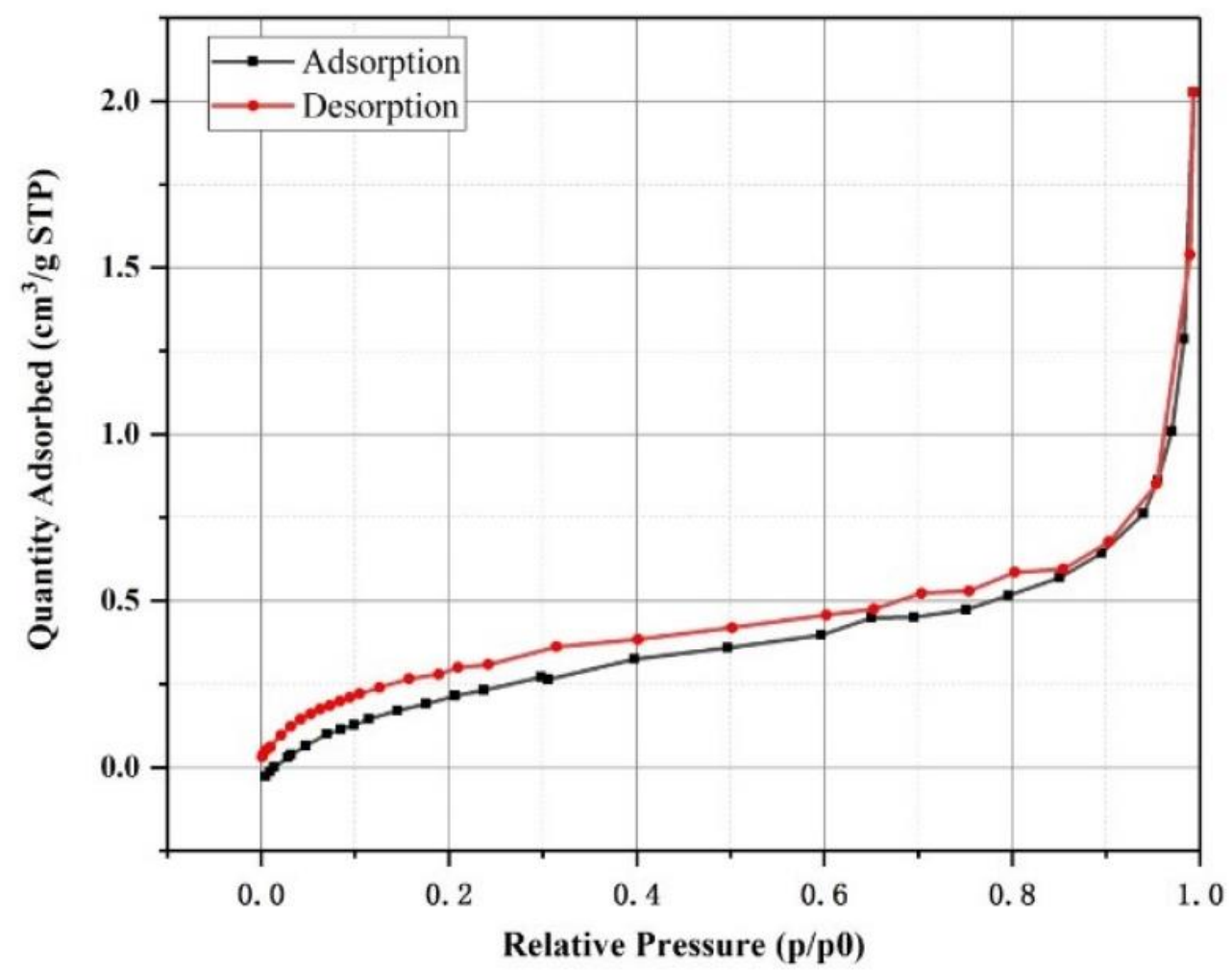

(a)

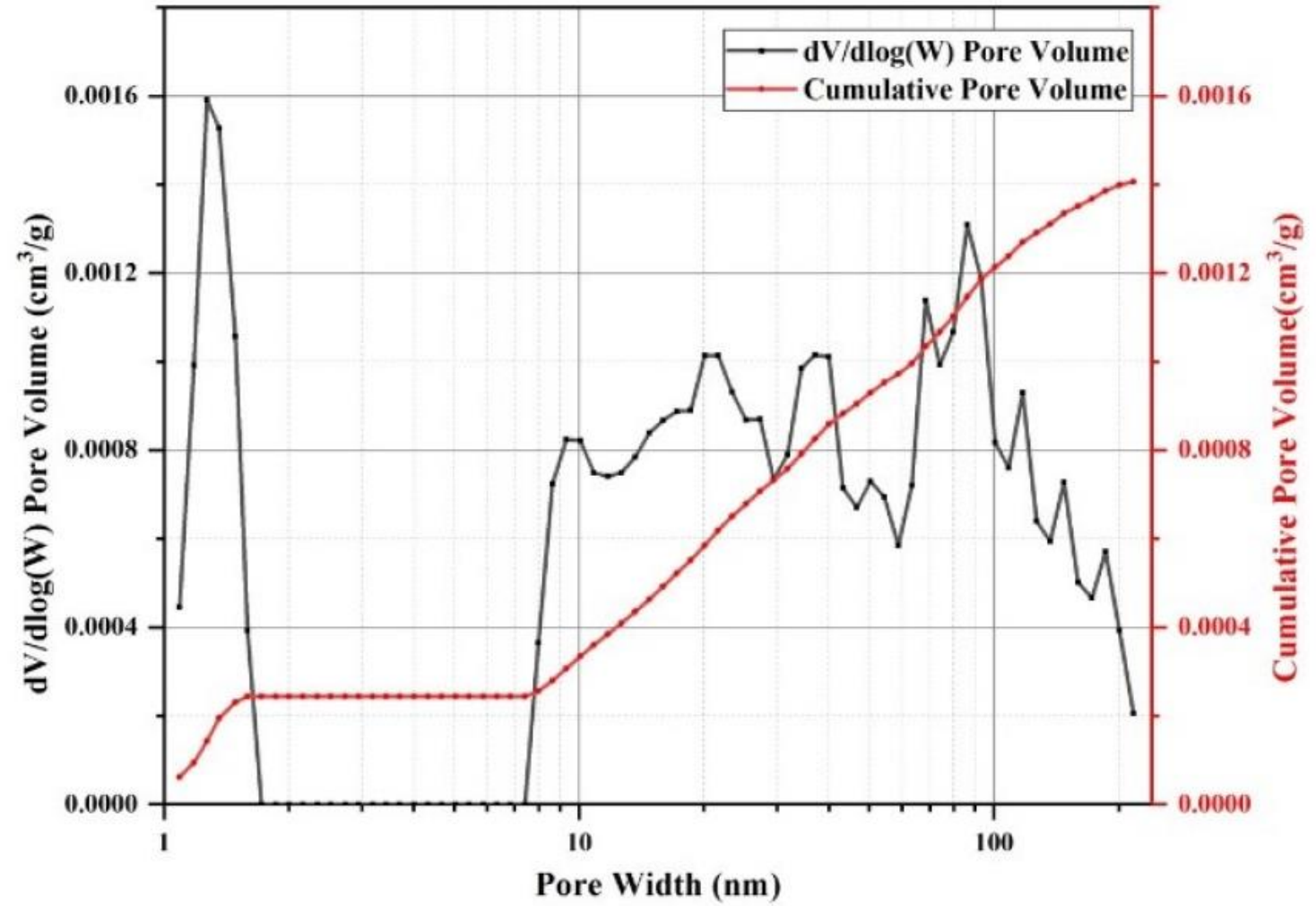

(b)

Figure 3. $\mathrm{N}_{2}$ adsorption-desorption isotherm of diatomite: (a) isotherm linear plot, and (b) pore size distribution and cumulative pore volume. 


\subsubsection{Thermo-Physical Properties of the DP Composite}

Figure 4 shows the DSC curves of paraffin and the DP composite. The melting and solidification temperatures of paraffin were $21.75^{\circ} \mathrm{C}$ and $19.85^{\circ} \mathrm{C}$, and the corresponding thermal latent heat values were $110.7 \mathrm{~J} / \mathrm{g}$ and $121.6 \mathrm{~J} / \mathrm{g}$, respectively. The melting and solidification temperatures of the DP composite were $22.94{ }^{\circ} \mathrm{C}$ and $21.75{ }^{\circ} \mathrm{C}$, and the corresponding latent heat values were $13.75 \mathrm{~J} / \mathrm{g}$ and $18.75 \mathrm{~J} / \mathrm{g}$, respectively. According to Equation (1), we can calculate that the impregnation ratio of paraffin in the DP composite was $14 \%$. These results are consistent with those of Guo et al. [24]. In their study, the paraffin was encapsulated by diatomite and high-density polyethylene to prepare SSPCM, and the melting and solidification enthalpy were approximately $14.75 \mathrm{~J} / \mathrm{g}$ and $16.95 \mathrm{~J} / \mathrm{g}$, respectively.

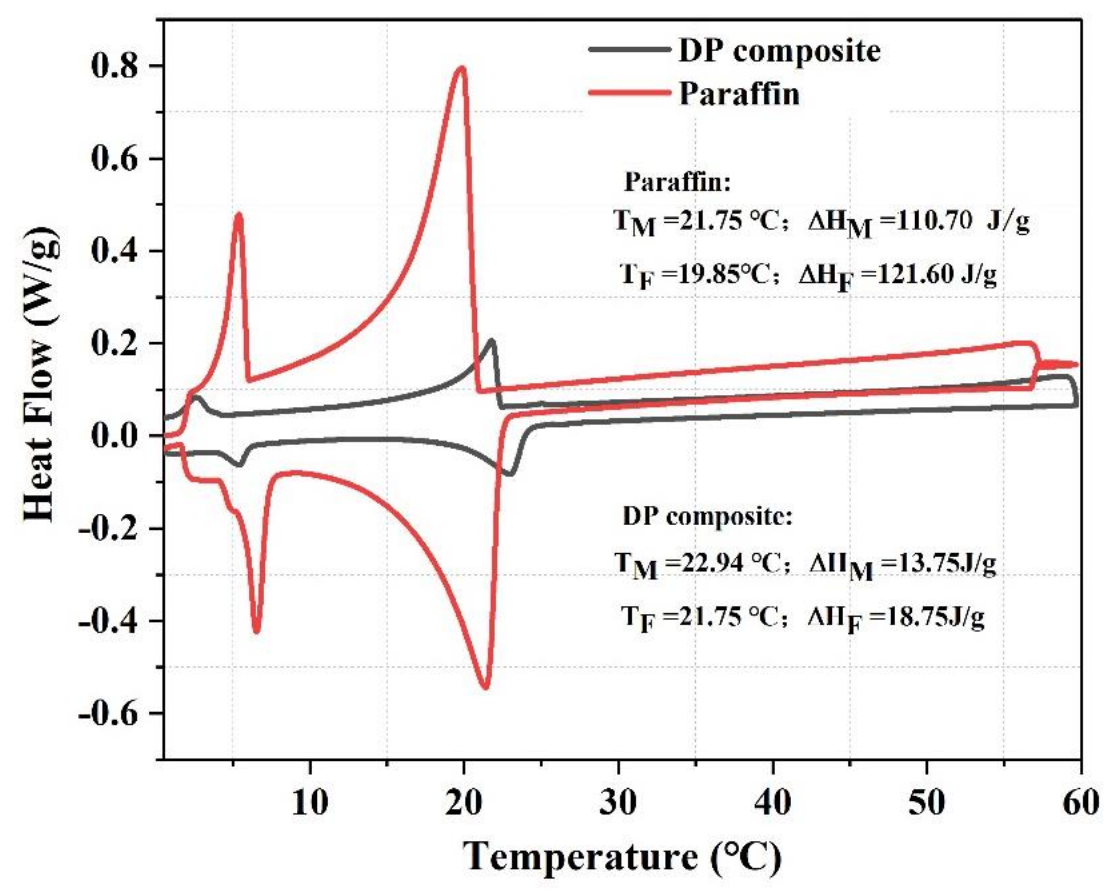

Figure 4. DSC curves of paraffin and diatomite/paraffin.

It is worth noting that the melting temperature of DP is higher than that of pure paraffin. This might be related to the special pore structure and natural convection of paraffin. For pure paraffin, when the ambient temperature is higher than the melting temperature of pure paraffin, the paraffin surrounding and in contact with the environment will melt at first, and then the heat will flow to the unmelted paraffin by the driving force of natural convection, which could accelerate the melting of the pure paraffin. However, when the paraffin distributes evenly in the pores of diatomite, the flow of the paraffin is limited, especially in the unconnected pores, so the natural convection phenomenon is greatly weakened when paraffin is stored in the unconnected pores of diatomite [38].

Figure 5 shows the TGA curves of paraffin and DP. The paraffin began to decompose at around $180^{\circ} \mathrm{C}$ and then volatilized completely at $315^{\circ} \mathrm{C}$. In contrast, the decomposition of DP occurred at temperatures ranging from $160^{\circ} \mathrm{C}$ to $230^{\circ} \mathrm{C}$. The DP composite was more sensitive to temperature change during the heating process than the pure paraffin due to the higher thermal conductivity of DP. Although the DP has a lower decomposition temperature, it still meets the requirements of thermal stability for practical applications. According to the results shown in Figure $5 b$, the content of paraffin within DP was approximately $15 \mathrm{wt}$ \%, which is close to the result of DSC (14 wt. \%). 

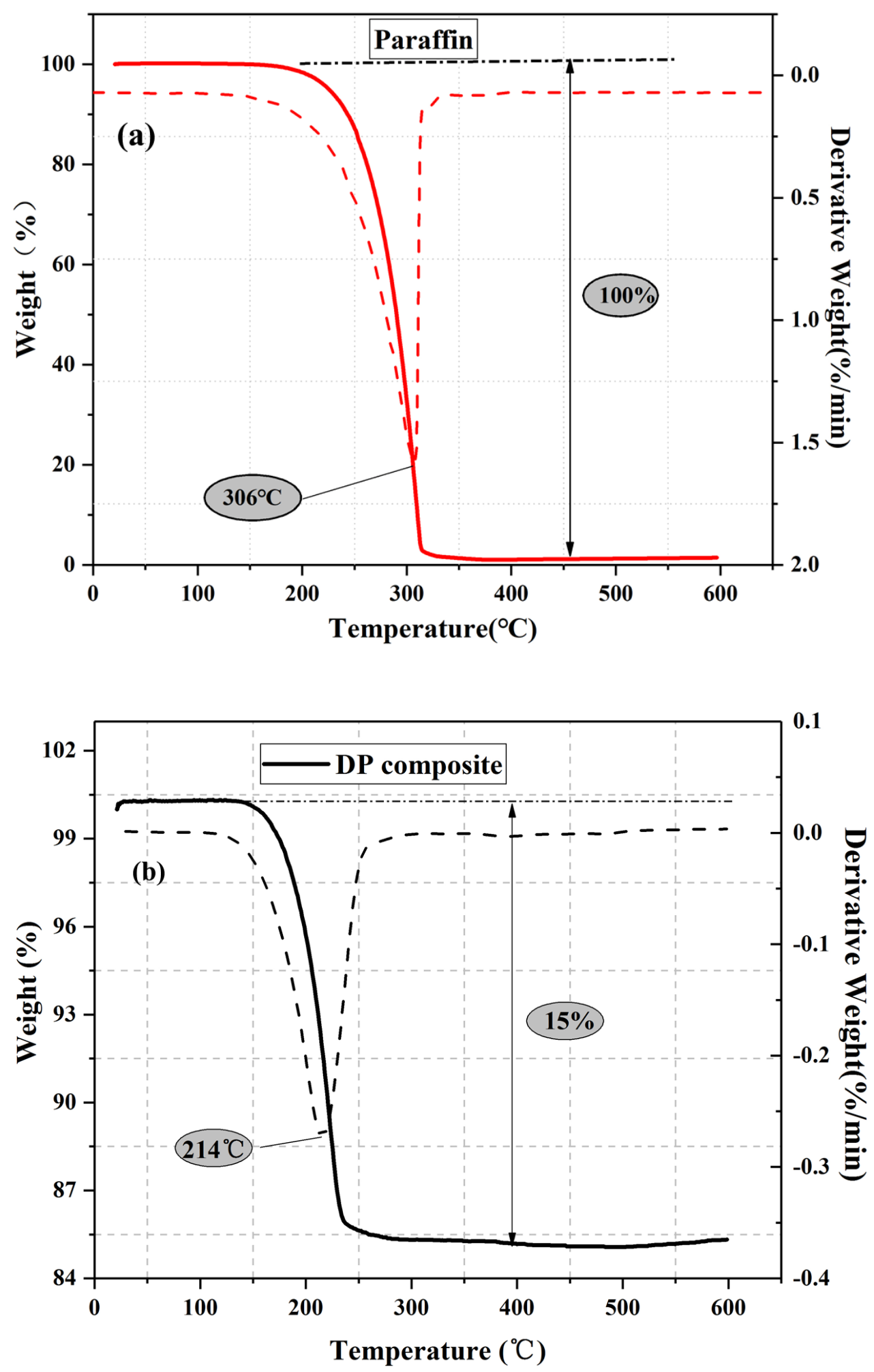

Figure 5. TGA and derivative of the TGA (DTG) curves: (a) paraffin and (b) diatomite/paraffin.

\subsubsection{Chemical Structure of the DP Composite}

Figure 6 shows the FT-IR curves of paraffin, diatomite and DP. Paraffin shows obvious absorption peaks at positions of $718 \mathrm{~cm}^{-1}, 1466 \mathrm{~cm}^{-1}, 1473 \mathrm{~cm}^{-1}, 2849 \mathrm{~cm}^{-1}$ and $2918 \mathrm{~cm}^{-1}$. The absorption peak at $718 \mathrm{~cm}^{-1}$ is related to the rocking vibration of $\mathrm{CH}_{2}$ [39]. The asymmetric stretching vibration of the $\mathrm{C}=\mathrm{O}$ functional group causes a peak at $1466 \mathrm{~cm}^{-1}$, 
and the peak at $1473 \mathrm{~cm}^{-1}$ is related to the asymmetric stretching vibration of the $\mathrm{CH}_{2}$ group [30]. The weak absorption peaks at $2345 \mathrm{~cm}^{-1}$ and $2461 \mathrm{~cm}^{-1}$ are caused by the $\mathrm{CO}_{2}$ antisymmetric stretching mode [40], which is affected by the atmospheric $\mathrm{CO}_{2}$, and the absorption peaks at $2849 \mathrm{~cm}^{-1}$ and $2918 \mathrm{~cm}^{-1}$ are ascribed to the stretching vibrations of $\mathrm{CH}_{2}$ and $\mathrm{CH}_{3}$, respectively [30]. Diatomite has four distinct absorption peaks at $455 \mathrm{~cm}^{-1}$, $791 \mathrm{~cm}^{-1}, 1092 \mathrm{~cm}^{-1}$, and $3444 \mathrm{~cm}^{-1}$, and the first three are related to the bending vibration of Si-O $\left(455 \mathrm{~cm}^{-1}\right)$, the bending vibration of Si-O-H $\left(791 \mathrm{~cm}^{-1}\right)$, and the asymmetric stretching vibration of Si-O-Si $\left(1092 \mathrm{~cm}^{-1}\right)$, respectively [25,41]. The broadband of $3444 \mathrm{~cm}^{-1}$ corresponds to the vibration of the $\mathrm{O}-\mathrm{H}$ mode in the physical adsorption of $\mathrm{H}_{2} \mathrm{O}$, and the bending vibration of the water molecules retained in the diatomaceous silica matrix [42]. The absorption peaks of DP distribute at positions of $455 \mathrm{~cm}^{-1}, 791 \mathrm{~cm}^{-1}, 1092 \mathrm{~cm}^{-1}$, $1465 \mathrm{~cm}^{-1}, 2354 \mathrm{~cm}^{-1}, 2850 \mathrm{~cm}^{-1}$ and $2916 \mathrm{~cm}^{-1}$, which are contained within the peaks of paraffin or diatomite. This indicates that there is only a simple physical adsorption between paraffin and diatomite. Therefore, the DP composite is chemically compatible.

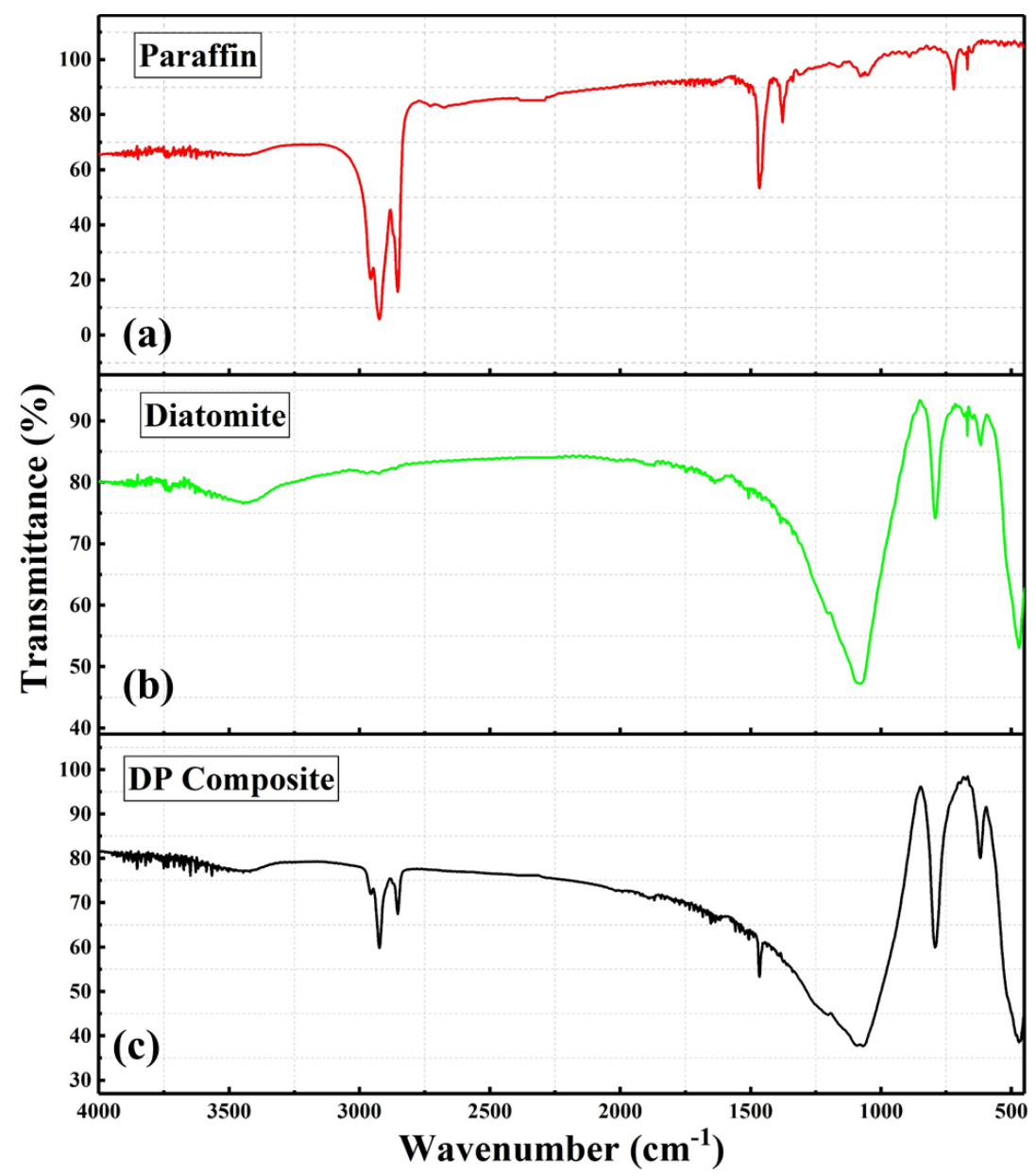

Figure 6. FT-IR spectra: (a) paraffin, (b) diatomite, and (c) diatomite/paraffin.

\subsubsection{Thermal Cycle Test}

Figure 7 and Table 3 show that the changes in the phase change temperature and enthalpy of DP after 300 cycles and 600 cycles are not significant. It can be seen that the melting temperature and solidification temperature of DP were basically the same before and after the thermal cycles, and that the average thermal latent heat value decreased by $0.79 \mathrm{~J} / \mathrm{g}$ only. This indicates that the newly prepared DP is thermally stable and reliable over a long period of time, and is considered a good potential candidate for practical application. 


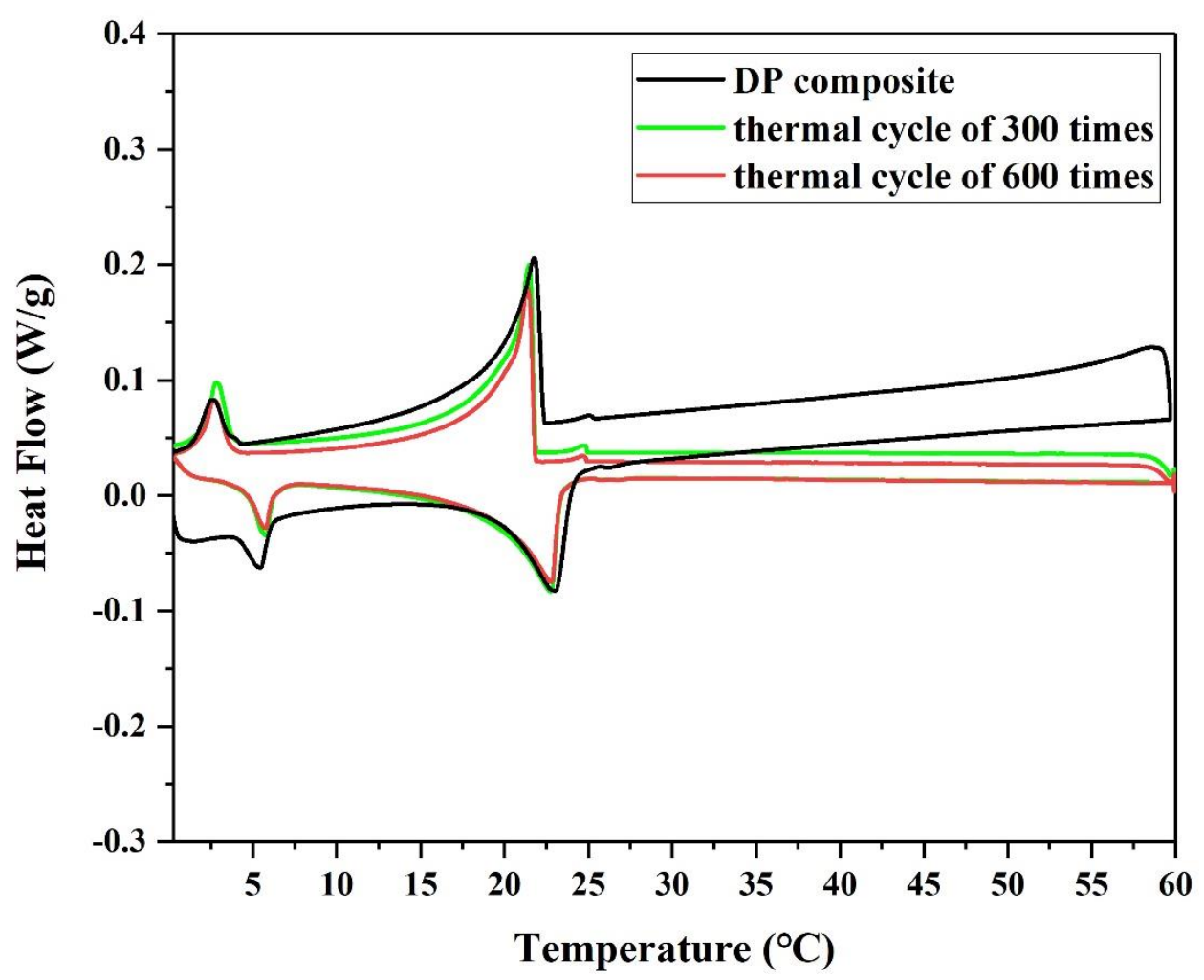

Figure 7. DSC curves of diatomite/paraffin with thermal cycles of 0,300 and 600 times.

Table 3. The phase change temperature and enthalpy after thermal cycles of 0, 300 and 600 times.

\begin{tabular}{cccccc}
\hline $\begin{array}{c}\text { Thermal } \\
\text { Cycle Times }\end{array}$ & $\mathbf{T}_{\mathbf{M}}$ & $\boldsymbol{\Delta} \mathbf{H}_{\mathbf{M}}$ & $\mathbf{T}_{\mathbf{F}}$ & $\boldsymbol{\Delta} \mathbf{H}_{\mathbf{F}}$ & $\begin{array}{c}\text { Average Enthalpy } \\
\left(\left(\mathbf{\Delta H}_{\mathbf{M}}+\boldsymbol{\Delta} \mathbf{H}_{\mathbf{F}}\right) / \mathbf{2}\right)\end{array}$ \\
\hline $\mathbf{0}$ & $22.94^{\circ} \mathrm{C}$ & $13.75 \mathrm{~J} / \mathrm{g}$ & $21.75^{\circ} \mathrm{C}$ & $18.75 \mathrm{~J} / \mathrm{g}$ & $16.25 \mathrm{~J} / \mathrm{g}$ \\
$\mathbf{3 0 0}$ times & $22.77^{\circ} \mathrm{C}$ & $15.05 \mathrm{~J} / \mathrm{g}$ & $21.45^{\circ} \mathrm{C}$ & $17.36 \mathrm{~J} / \mathrm{g}$ & $16.21 \mathrm{~J} / \mathrm{g}(-0.04 \mathrm{~J} / \mathrm{g})$ \\
$\mathbf{6 0 0 ~ t i m e s}$ & $22.79^{\circ} \mathrm{C}$ & $14.02 \mathrm{~J} / \mathrm{g}$ & $21.37^{\circ} \mathrm{C}$ & $16.89 \mathrm{~J} / \mathrm{g}$ & $15.46 \mathrm{~J} / \mathrm{g}(-0.79 \mathrm{~J} / \mathrm{g})$ \\
\hline
\end{tabular}

\subsection{Mechanical Properties of the DP/Gypsum Composite}

Figure 8 shows the compressive strength results of all samples at 7 days. The compressive strength of the control mix (G-C) was $18.80 \mathrm{MPa}$. When $10 \%$ and $20 \% \mathrm{DP}$ was added, the compressive strengths of the G-10\%DP and G-20\%DP samples decreased by $3.7 \%$ and $10.6 \%$, respectively, when compared to the control (G-C). Although the flexural strength of G-10\%DP is higher than the control (see Figure 9), it seems that the strength of gypsum generally decreased with increasing DP content. This may be due to the change in the microstructure of the materials. Figure 10 shows the microstructure of the composite materials. As shown in Figure 10a, DP is a discontinuous phase in the gypsum matrix, while diatomite is a porous material (see Figure 2). Additionally, the interfaces between diatomite and gypsum are weak. Therefore, the mechanical strengths of DP/gypsum decreased with the increase in DP content.

$\mathrm{CF}$, with high tensile modulus values ranging from 230 to $500 \mathrm{GPa}$, can improve the mechanical properties of the DP/gypsum composites. When $1 \mathrm{wt}$. \% carbon fiber was added, the compressive strengths of G-10\%DP-1\%CF and G-20\%DP-1\%CF increased by $29.8 \%$ and $9.0 \%$, respectively, compared to the control (G-C). The effect of CF on flexural strength is much more significant. As seen in Figure 9, the flexural strengths of G-10\%DP$1 \% \mathrm{CF}$ and G-20\%DP-1\%CF increased by $176.0 \%$ and $56.0 \%$, respectively, when compared to the control. This remarkable improvement is mainly due the high strength and toughness of $\mathrm{CF}$, as well as its pull-out effect on the gypsum matrix that restrains the crack development. Specifically, as shown in Figure $10 \mathrm{~b}, \mathrm{c}$, the CF, with an average diameter of $7 \mu \mathrm{m}$ and 
length of $3 \mathrm{~mm}$, can cross the pores or defects $(<100 \mu \mathrm{m})$ that exist in the cement matrix, and thus it is able to restrain the crack development and separation under high tension and compression strengths. According to the test results, $\mathrm{CF}$ is considered effective in enhancing the mechanical properties of DP/gypsum, and the G-10\%DP-1\%CF composite displayed the best mechanical properties among the samples tested.

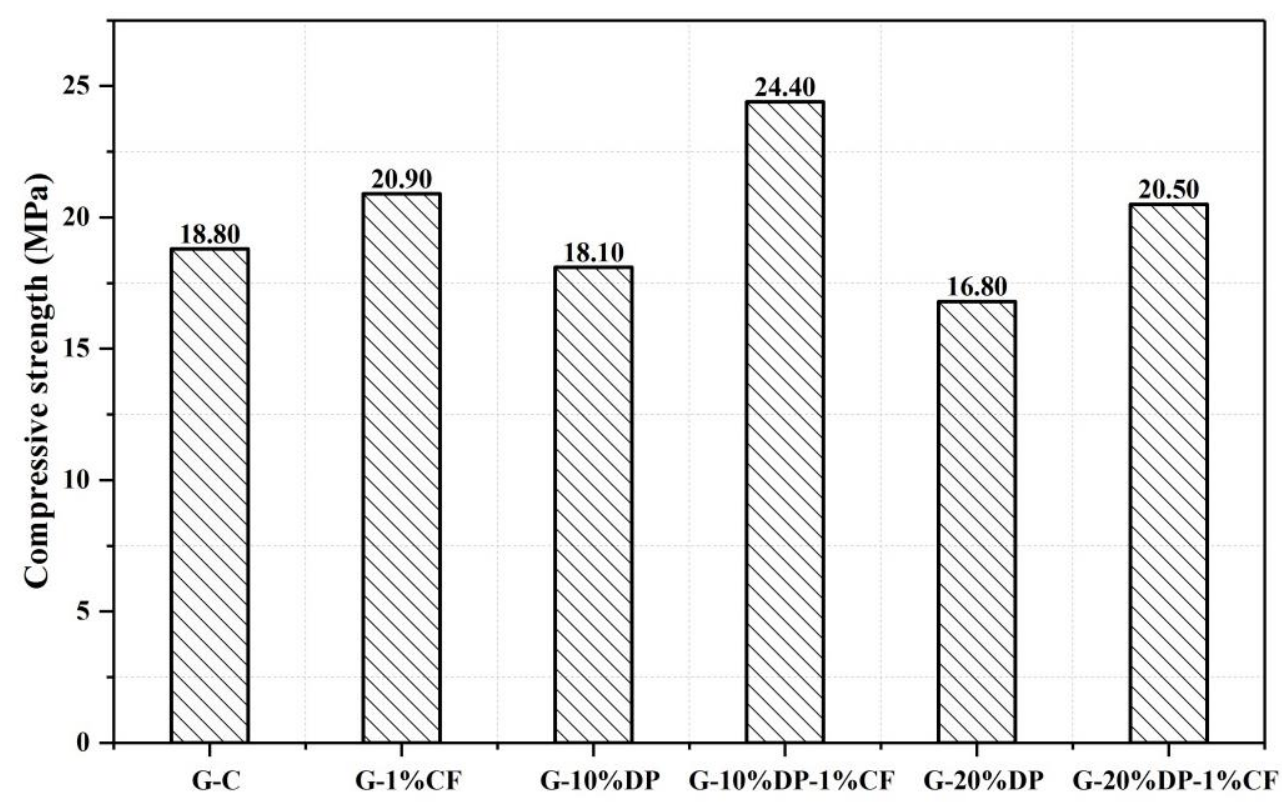

Figure 8. The compressive strength of the diatomite/paraffin/gypsum composites after 7 days curing.

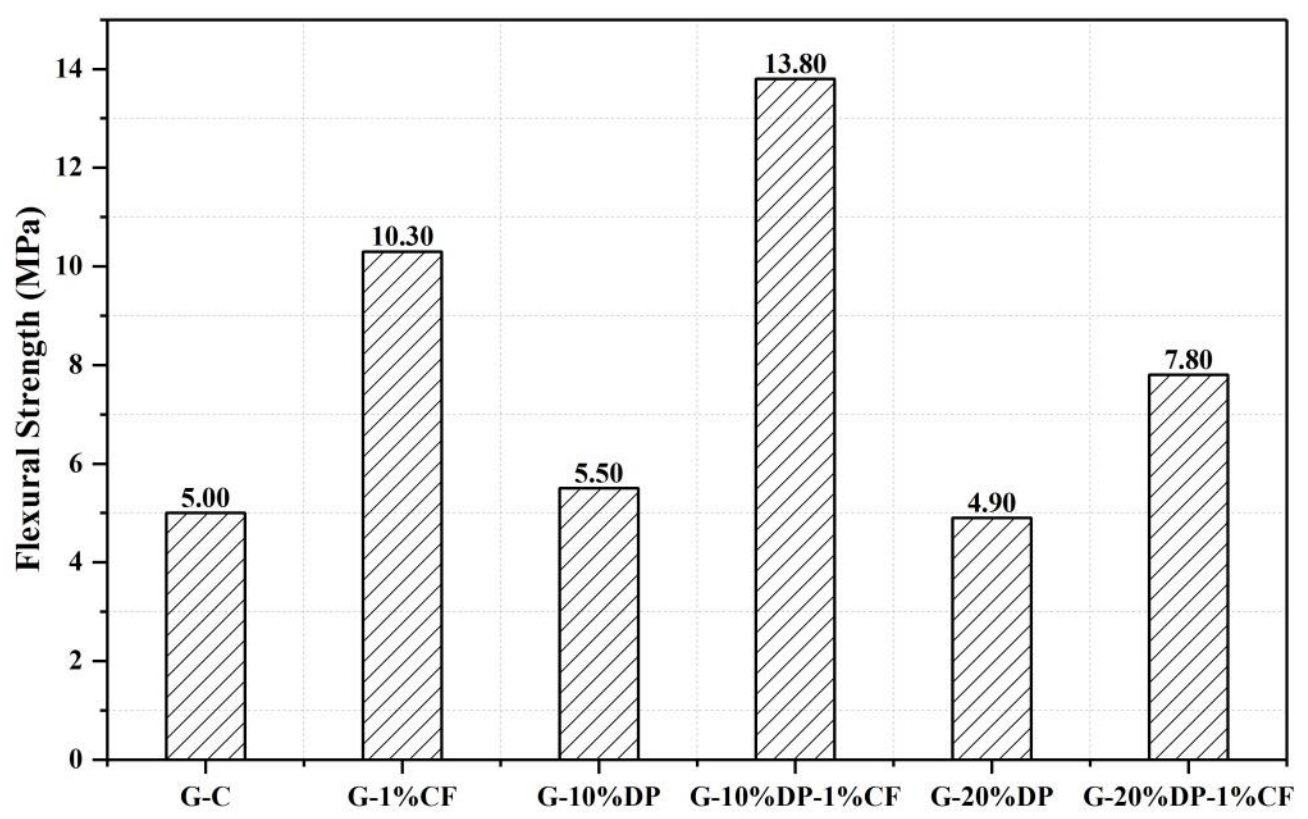

Figure 9. The flexural strength of the diatomite/paraffin/gypsum after 7 days curing. 

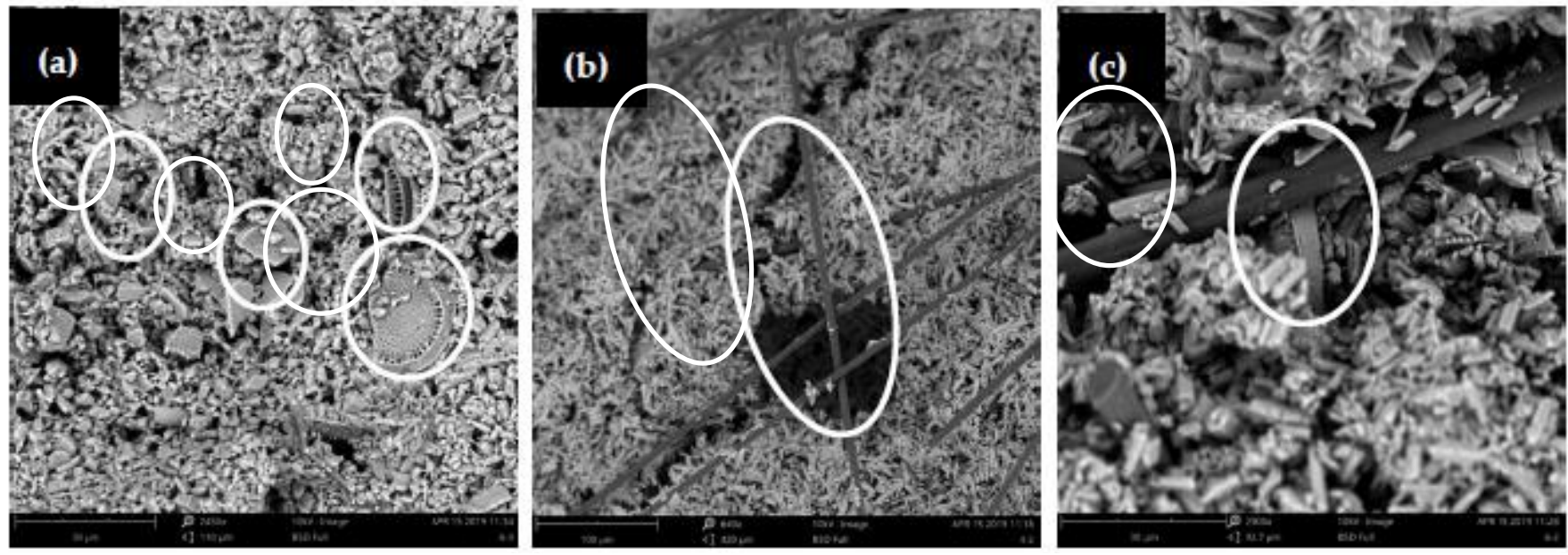

Figure 10. SEM images of microstructure of the composites: (a) the 20\% diatomite/paraffin/gypsum; (b) gypsum with 1\% carbon fiber; and (c) gypsum with $20 \%$ diatomite/paraffin and $1 \%$ carbon fiber.

\subsection{Thermal Conductivity, Density and Specific Heat Capacity of the DP/Gypsum Composites}

Figure 11 shows the thermal conductivity of pure gypsum and DP/gypsum composites. The thermal conductivity of pure gypsum was $0.86 \mathrm{~W} /(\mathrm{m} \cdot \mathrm{K})$. The thermal conductivity of the DP/gypsum composites decreased as the proportion of DP increased. When $10 \%$ and $20 \%$ DP were added, the thermal conductivity of G-10\% DP and G-20\% DP decreased to $0.76 \mathrm{~W} /(\mathrm{m} \cdot \mathrm{K})$ and $0.59 \mathrm{~W} /(\mathrm{m} \cdot \mathrm{K})$, respectively. This is due to the fact that the thermal conductivity of DP (less than $0.40 \mathrm{~W} /(\mathrm{m} \cdot \mathrm{K})$ ) [43-45] is much lower than that of the pure gypsum. However, the addition of $1 \% \mathrm{CF}$ can increase the thermal conductivity of G-10\% DP-1\% CF and G-20\% DP-1\% CF by $10.5 \%$ and $20.3 \%$, respectively, compared to the corresponding samples without $\mathrm{CF}$. There are two main reasons for the improvement in thermal conductivity: First, the CF can improve the overall thermal conductivity of the composites. Second, the CF were well dispersed and inter-connected in the gypsum matrix, thus offering more channels for heat transfer [46]. Similar results can be found in the literature. In the research of Cheng et al. [47], the thermal conductivity of a beeswaxtetradecanol/expanded perlite composite increased from $0.443 \mathrm{~W} /(\mathrm{m} \cdot \mathrm{K})$ to $1.245 \mathrm{~W} /(\mathrm{m} \cdot \mathrm{K})$ because of the addition of $2 \% \mathrm{CF}$. Besides this, Huang et al. [48] incorporated $5 \% \mathrm{CF}$ into an acetyl alcohol/high density polyethylene composite, and the resulting thermal conductivity increased from $0.2125 \mathrm{~W} /(\mathrm{m} \cdot \mathrm{K})$ to $0.4719 \mathrm{~W} /(\mathrm{m} \cdot \mathrm{K})$. Furthermore, with the increase in DP addition, the density of the gypsum decreased, as shown in Figure 12. When incorporating $20 \mathrm{wt}$. \% DP, the density of gypsum decreased from $1902.3 \mathrm{~kg} / \mathrm{m}^{3}$ to $1626.7 \mathrm{~kg} / \mathrm{m}^{3}$. Therefore, the use of diatomite/paraffin/gypsum composites can also reduce the weight of the whole building. Figure 13 demonstrated that the specific heat capacity increased along with the addition of DP. This is due to the higher specific heat capacity of the incorporated DP in comparison to pure gypsum. Specifically, the specific heat capacities of G-C, G-10\% DP, G-10\% DP- $1 \%$ CF, G-20\% DP and G-20\% DP- $1 \%$ CF were $0.93 \mathrm{~J} /\left(\mathrm{g} \cdot{ }^{\circ} \mathrm{C}\right), 1.10 \mathrm{~J} /\left(\mathrm{g} \cdot{ }^{\circ} \mathrm{C}\right)$, $1.05 \mathrm{~J} /\left(\mathrm{g} \cdot{ }^{\circ} \mathrm{C}\right), 1.31 \mathrm{~J} /\left(\mathrm{g} \cdot{ }^{\circ} \mathrm{C}\right)$ and $1.28 \mathrm{~J} /\left(\mathrm{g} \cdot{ }^{\circ} \mathrm{C}\right)$ at $15{ }^{\circ} \mathrm{C}$, respectively. At $35^{\circ} \mathrm{C}$, the values were $0.99 \mathrm{~J} /\left(\mathrm{g} \cdot{ }^{\circ} \mathrm{C}\right), 1.13 \mathrm{~J} /\left(\mathrm{g} \cdot{ }^{\circ} \mathrm{C}\right), 1.12 \mathrm{~J} /\left(\mathrm{g} \cdot{ }^{\circ} \mathrm{C}\right), 1.32 \mathrm{~J} /\left(\mathrm{g} \cdot{ }^{\circ} \mathrm{C}\right)$ and $1.31 \mathrm{~J} /\left(\mathrm{g} \cdot{ }^{\circ} \mathrm{C}\right)$, accordingly. 


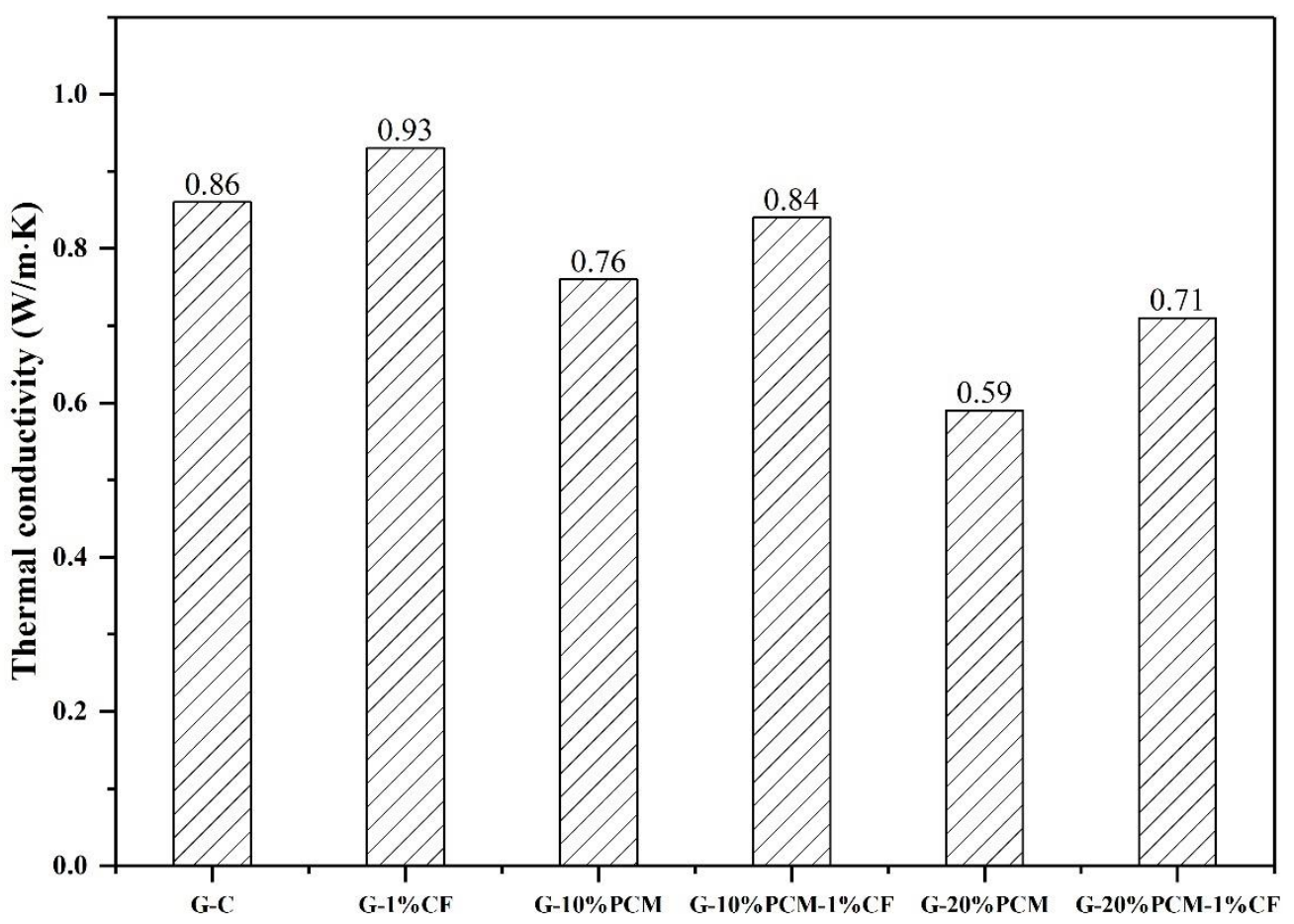

Figure 11. The thermal conductivity of diatomite/paraffin/gypsum composites.

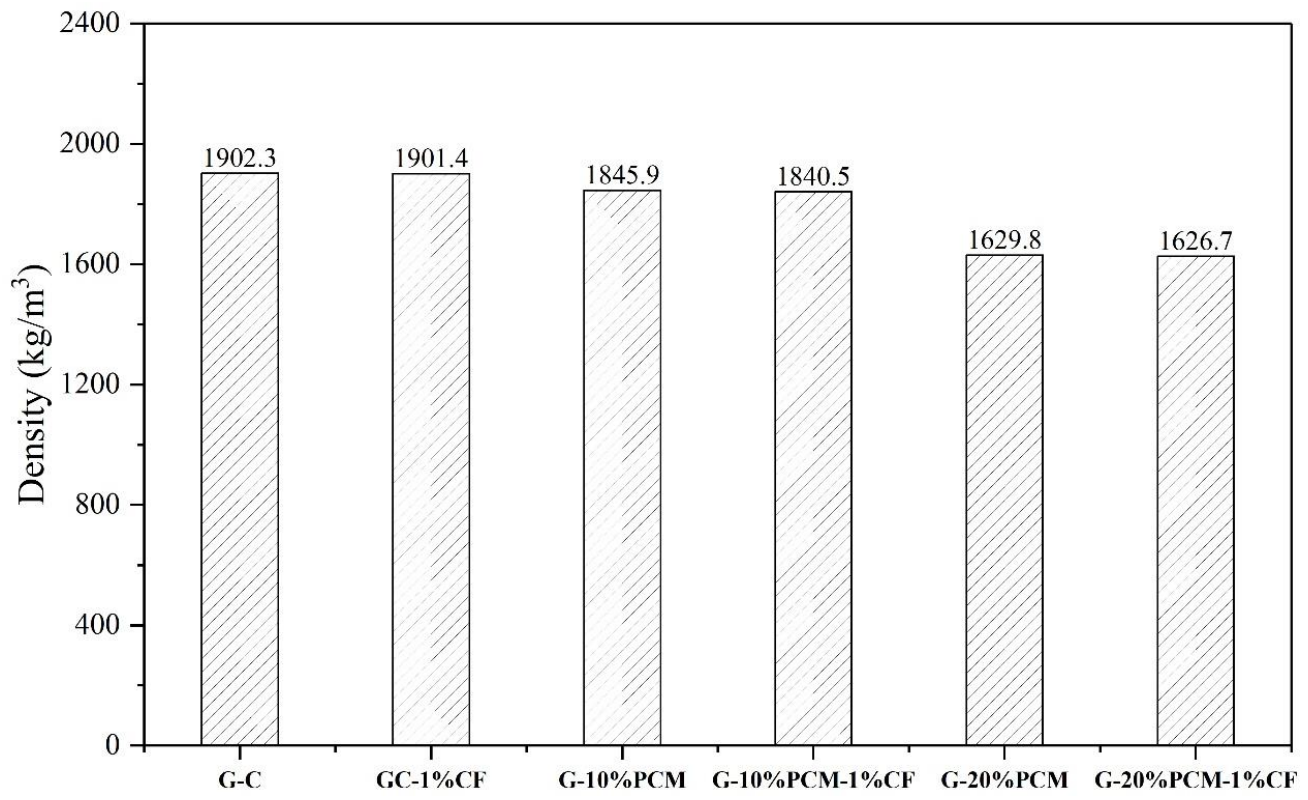

Figure 12. The density of diatomite/paraffin/gypsum composites. 


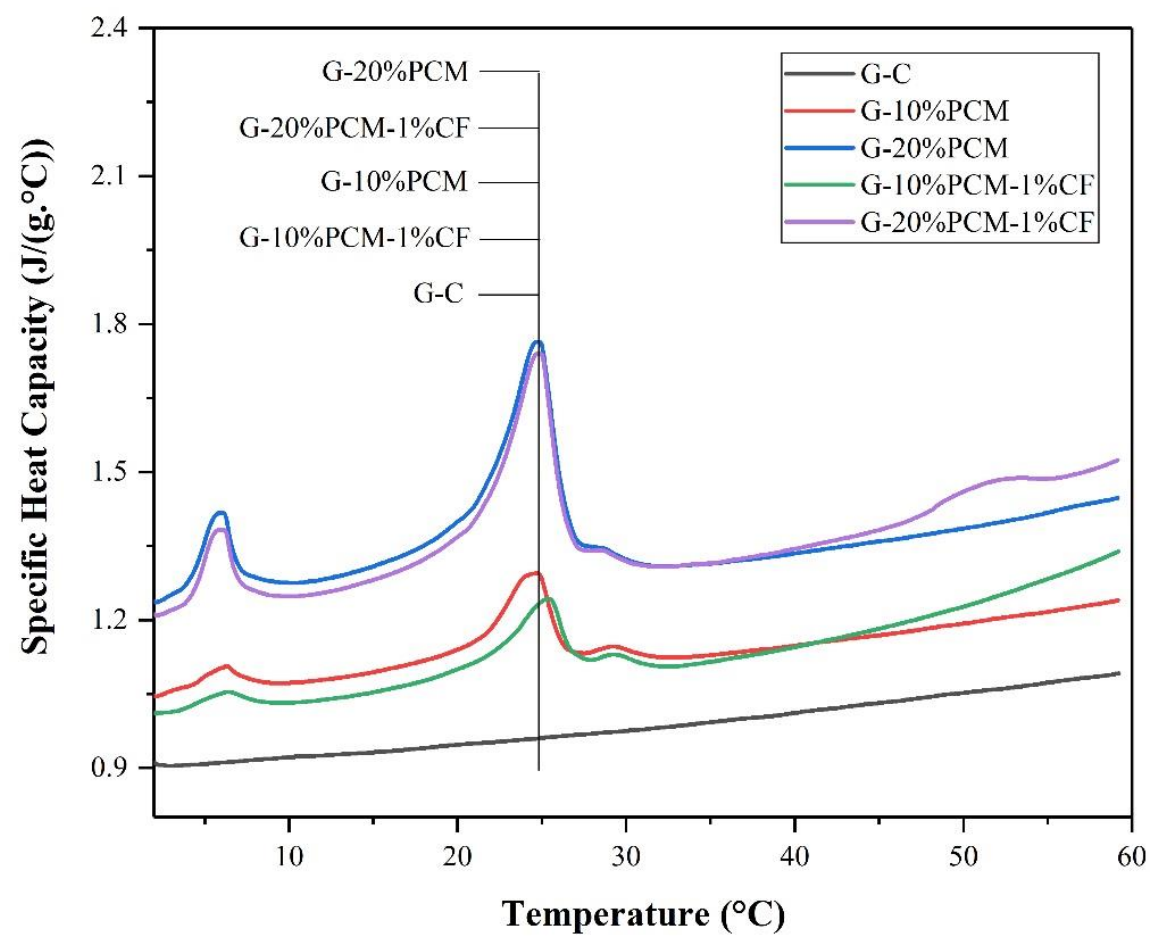

Figure 13. The specific heat capacity of diatomite/paraffin/gypsum composites.

\subsection{Thermo-Regulated Performance of the DP/Gypsum Composite}

Figure 14 illustrates the indoor temperature variations of different room models. When the room models were heated for $2.83 \mathrm{~h}$, the maximum indoor temperature of the control model (G-C) was $27.4^{\circ} \mathrm{C}$. However, the highest indoor temperatures of the G$10 \%$ DP and G-20\% DP models were $25.9^{\circ} \mathrm{C}$ and $24.5^{\circ} \mathrm{C}$, reducing by $1.5^{\circ} \mathrm{C}$ and $2.9^{\circ} \mathrm{C}$, respectively. Obviously, the indoor temperature decreased as the DP content increased. Nevertheless, when $1 \mathrm{wt}$. \% carbon fiber was added, the peak temperature of G-10\% DP- $1 \% \mathrm{CF}$ was $25.7^{\circ} \mathrm{C}$, reducing by $1.7^{\circ} \mathrm{C}$ compared to the control, while the maximum indoor temperature of G-20\% DP- $1 \%$ CF was $24.3^{\circ} \mathrm{C}$, which is $3.1{ }^{\circ} \mathrm{C}$ lower than that of the control room. 


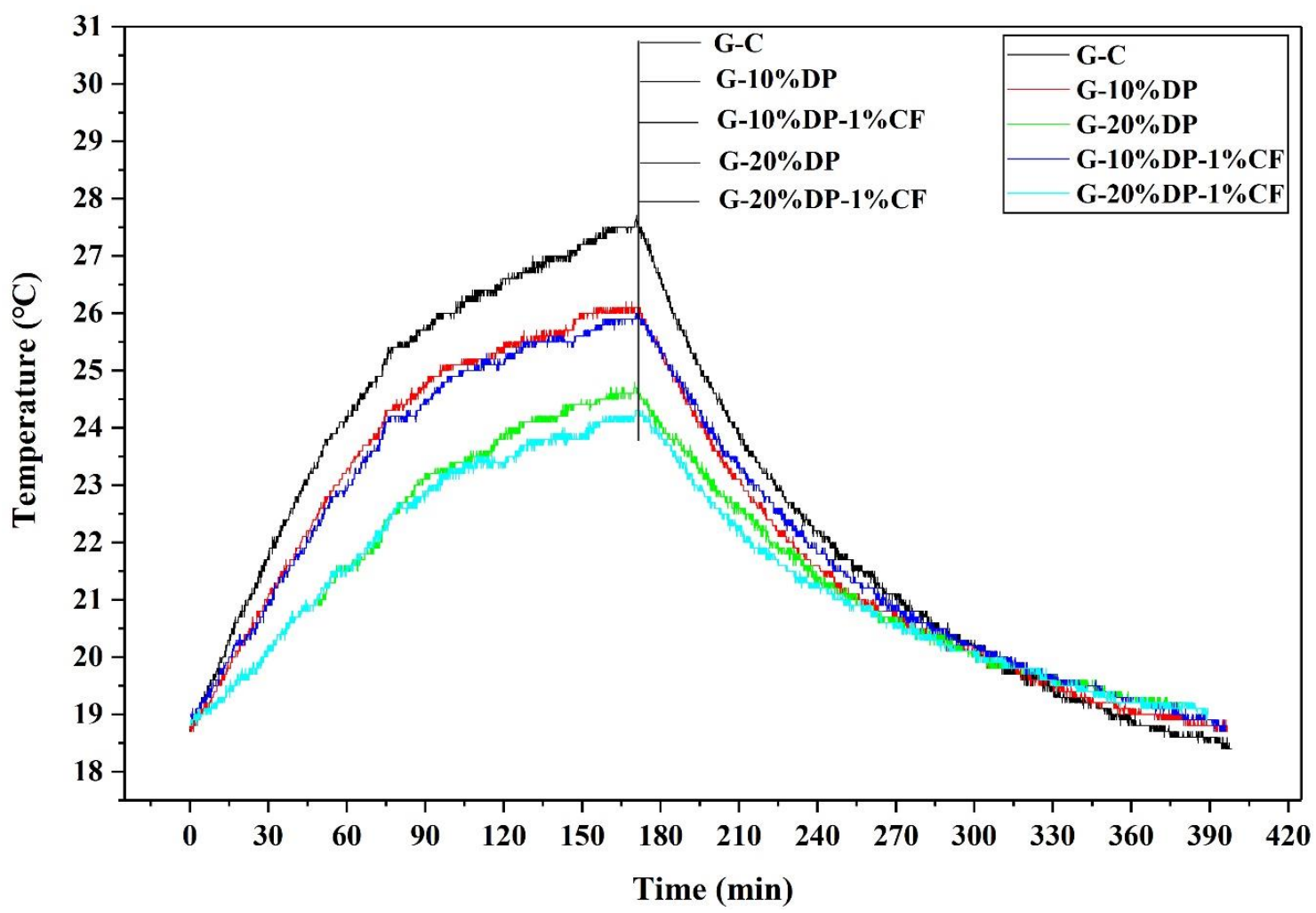

Figure 14. The curves of the indoor temperature variation of five small house models.

As shown in the schematic diagram of Figure 15, the reasons for the reductions in indoor temperatures are summarized as follows: (1) Once the outdoor temperature exceeded the phase change temperature of paraffin, the PCM began to melt and absorb heat, so the heat passing through the gypsum panel could be reduced. This in turn caused the indoor temperature to rise slowly, and resulted in a drop in the maximum indoor temperature; (2) CF greatly improved the thermal conductivity of DP/gypsum and the heat transfer of the PCM.

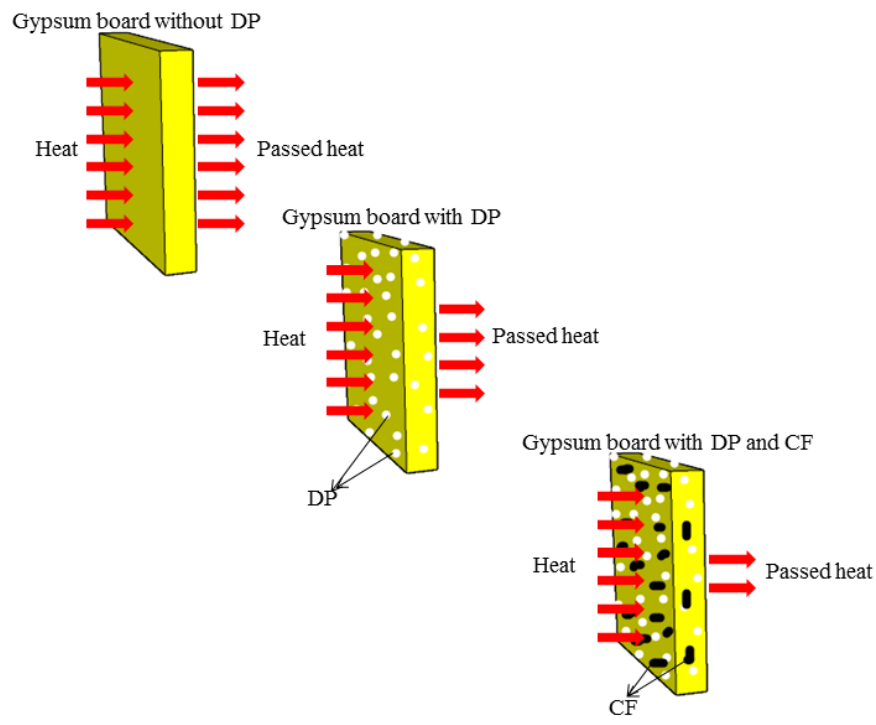

Figure 15. The schematic diagram of the thermo-regulating mechanism of different diatomite/paraffin panels.

Although the DP used in this study has a small impregnation ratio (15\%), it could help improve the thermo-regulation performance by reducing the indoor temperature by $3.1^{\circ} \mathrm{C}$. 
The application of DP within walls and roofs could not only reduce energy consumption, but also shift peaks in electricity consumption, contributing to the economic benefits and $\mathrm{CO}_{2}$ emission reduction.

\subsection{Feasibility Analysis}

\subsubsection{Economic Feasibility}

According to data from the 2019 Shenzhen Municipal Bureau of Statistics, the average housing area of every person in Shenzhen city of China was $21.12 \mathrm{~m}^{2}$, while the average area that required air conditioning was approximately $43 \mathrm{~m}^{2}$ for a household of four family members. The National Refrigeration Department announced that the typical power of an air conditioner was $3000 \mathrm{~W}$ for an area from $42 \mathrm{~m}^{2}$ to $52 \mathrm{~m}^{2}$. Given the weather conditions in Shenzhen, air conditioners are normally required in the months from April to November, and are expected to operate for a period of $16 \mathrm{~h}$ per day. However, an air conditioner is usually intermittently operated, so the empirical operating time was then assumed to be $40-50 \%$ of the usage time. Therefore, the annual power consumption by air conditioning per household was calculated as $3000 \times 16 \times 6 \times 30 \times 0.45 / 1000=3888 \mathrm{~kW} \cdot \mathrm{h}$, or $648 \mathrm{~kW} \cdot \mathrm{h}$ monthly (during the 6 months of operating). The Shenzhen Power Grid Department announced that the cost of electricity would be $0.98 \mathrm{RMB} / \mathrm{kW} \cdot \mathrm{h}$ when the electricity consumption in the current month exceeds $600 \mathrm{~kW} \cdot \mathrm{h}$. As a result, the air conditioning cost per household would be $3810.24 \mathrm{RMB} /$ year.

Based on the household's annual air conditioning power consumption, the daily power consumption would be $10.65 \mathrm{~kW} \cdot \mathrm{h} /$ day or $38.35 \mathrm{MJ} /$ day. To absorb $38.35 \mathrm{MJ}$ of heat, $2360 \mathrm{~kg}$ of DP is required, comprising $354 \mathrm{~kg}$ paraffin, $2006 \mathrm{~kg}$ diatomite, 20,060 kg gypsum and $200.6 \mathrm{~kg}$ CF. The market prices of paraffin, diatomite, gypsum and CF were $8.5 \mathrm{RMB} / \mathrm{kg}, 2.2 \mathrm{RMB} / \mathrm{kg}, 0.5 \mathrm{RMB} / \mathrm{kg}$ and $85.0 \mathrm{RMB} / \mathrm{kg}$, respectively. It is worthwhile to point out that the efficiency of DP depends on temperature and weather conditions, so it was assumed that the PCM had a working efficiency of 50\% [49]. Moreover, according to the authors' experience, it will take 30 working days to prepare $2660 \mathrm{~kg}$ DP, and 3 working days to fabricate $\mathrm{DP} /$ gypsum. The labor cost is approximately $300 \mathrm{RMB} /$ day, and thus the total labor cost is RMB 9900. Based on the above discussions, the payback period of applying structural-functional integrated energy storage gypsum board was 23.31 years, as indicated in Table 4, which is much less than the service life of the building, and it is considered suitable to be used as building components.

Table 4. The cost-benefit analysis of the application of structural-functional integrated energy storage gypsum board.

\begin{tabular}{|c|c|c|c|c|c|c|c|}
\hline \multicolumn{5}{|c|}{$\begin{array}{c}\text { The Cost of Using Structural-Functional Integrated Energy Storage } \\
\text { Gypsum Board (RMB) }\end{array}$} & $\begin{array}{c}\text { The Use } \\
\text { Efficiency of } \\
\text { DP Panel (\%) }\end{array}$ & $\begin{array}{c}\text { Electricity } \\
\text { Consumption } \\
\text { per Year (RMB) }\end{array}$ & $\begin{array}{c}\text { Static } \\
\text { Payback } \\
\text { Period (Year) }\end{array}$ \\
\hline $\begin{array}{c}\text { Total cost } \\
\text { of paraffin } \\
354 \times 8.5\end{array}$ & $\begin{array}{l}\text { Total cost of } \\
\text { diatomite } \\
2006 \times 2.2\end{array}$ & $\begin{array}{c}\text { Total cost } \\
\text { of gypsum } \\
20,060 \times 0.5\end{array}$ & $\begin{array}{l}\text { Fabrication cost } \\
\qquad 33 \times 300\end{array}$ & $\begin{array}{c}\text { Total cost } \\
34,503.2\end{array}$ & 0.5 & 3810.24 & 23.31 \\
\hline
\end{tabular}

\subsubsection{Practical Feasibility}

According to the Global and Chinese Gypsum Board Industry Report (2014-2016) [50], the use of global gypsum board was up to 12.2 billion square meters in 2013, and the demand continues to grow. Therefore, the development of this kind of structural-functional integrated energy storage gypsum board is very promising. Besides this, the energy storage gypsum board mainly consists of paraffin, diatomite, gypsum and carbon fiber. These materials are easily accessible and inexpensive, so they can meet the application requirements.

\subsubsection{Environmental Feasibility}

From the above discussions, it is clear that each household would save $3888 \mathrm{kWh}$ of power consumption every year by using the energy storage gypsum board. According to 
the study of Mittal [51], the saving of each unit of electrical power is equivalent to saving $0.4 \mathrm{~kg}$ standard coal, and the emission of $0.95 \mathrm{~kg}$ carbon dioxide, $0.272 \mathrm{~kg}$ dust, $0.007 \mathrm{~kg}$ sulfur dioxide and $0.003 \mathrm{~kg}$ nitrogen oxide. Therefore, using the energy storage gypsum board can help each household to save a total of $1555.2 \mathrm{~kg}$ of standard coal, and prevent the emissions of $1057.54 \mathrm{~kg}$ dust, $3693.6 \mathrm{~kg}$ carbon dioxide, $27.22 \mathrm{~kg}$ sulfur dioxide and $11.66 \mathrm{~kg}$ nitrogen oxide annually. Clearly, it is highly feasible to apply the energy storage gypsum boards in buildings with respect to their environmental benefits.

\section{Conclusions}

In this study, a gypsum-based PCM composite reinforced with carbon fiber, a kind of structural-functional integrated energy storage building material, was developed. According to the results, the following conclusions are drawn:

(1) From the SEM and $\mathrm{N}_{2}$ adsorption, it can be seen that diatomite with a porous structure could provide enough space for storing paraffin. The impregnation ratio of paraffin in the diatomite was approximately $15 \mathrm{wt}$. \%;

(2) Based on the thermo-physical characteristics, thermal stability, chemical structure and thermal reliability of diatomite/paraffin, it can be concluded that the diatomite/paraffin composite is suitable for practical application;

(3) The compressive strength of gypsum decreased slightly with the increase in diatomite/paraffin content. However, adding $1 \%$ CF could increase the compressive and flexural strengths of G-10\% and DP- $1 \%$ CF by $29.8 \%$ and $176.0 \%$, respectively, when compared to the control. These improvements are due to the pull-out effect of carbon fiber restraining the cracks' development;

(4) When $1 \mathrm{wt}$. \% CF was added into the composite, the thermal conductivity of G-20\% DP increased to $0.71 \mathrm{~W} /(\mathrm{m} \cdot \mathrm{K})$ from $0.59 \mathrm{~W} /(\mathrm{m} \cdot \mathrm{K})$, with an increase of $20.3 \%$;

(5) The indoor temperature of the room model with a G-20\% DP-1\% CF composite panel was $3.1^{\circ} \mathrm{C}$ lower than that of the control. In general, the composite showed an excellent thermo-regulated performance;

(6) The payback period of applying CF-reinforced diatomite/paraffin/gypsum in residential buildings was only 23.31 years, which is much less than the average life span of building (60 years).

Author Contributions: B.Z. did the experiments and data analysis and wrote part of this paper. H.Y. did the experiments and data analysis and wrote part of this paper. T.X. did the data analysis. W.T. wrote part of this paper. H.C. provided the original ideas and did the experiments and data analysis. All authors have read and agreed to the published version of the manuscript.

Funding: The work presented in this paper was fully supported by a grant from Natural Science Foundation of China (51925804).

Data Availability Statement: Data sharing is not applicable to this article.

Acknowledgments: The authors would like to thank the Shenzhen University to support this research.

Conflicts of Interest: The authors declare no conflict of interest.

$\begin{array}{ll}\text { Abbreviations } \\ \text { PCM } & \text { Phase change material } \\ \text { SSPCM } & \text { Shape-stabilized phase change material } \\ \text { CF } & \text { Carbon fibers } \\ \text { DP } & \text { Diatomite/paraffin } \\ \text { FESEM } & \text { Field emission scanning electron microscope } \\ \text { BET } & \text { Brunauer Emmett Teller } \\ \text { DSC } & \text { Differential scanning calorimetry } \\ \text { TGA } & \text { Thermogravimetric analysis } \\ \text { FT-IR } & \text { Fourier transform infrared spectrometer }\end{array}$




\section{References}

1. Choi, S.H.; Park, J.; Ko, H.S.; Karng, S.W. Heat penetration reduction through PCM walls via bubble injections in buildings. Energy Convers. Manag. 2020, 221, 113187. [CrossRef]

2. Mizan, M.H.; Ueda, T.; Matsumoto, K. Enhancement of the concrete-PCM interfacial bonding strength using silica fume. Constr. Build. Mater. 2020, 259, 119774. [CrossRef]

3. Fateh, A.; Borelli, D.; Weinläder, H.; Devia, F. Cardinal orientation and melting temperature effects for PCM-enhanced light-walls in different climates. Sustain. Cities Soc. 2019, 51, 101766. [CrossRef]

4. Marin, P.; Saffari, M.; de Gracia, A.; Zhu, X.; Farid, M.M.; Cabeza, L.F.; Ushak, S. Energy savings due to the use of PCM for relocatable lightweight buildings passive heating and cooling in different weather conditions. Energy Build. 2016, 129, 274-283. [CrossRef]

5. Cunha, S.; Lima, M.; Aguiar, J.B. Influence of adding phase change materials on the physical and mechanical properties of cement mortars. Constr. Build. Mater. 2016, 127, 1-10. [CrossRef]

6. Memon, S.A.; Lo, T.Y.; Cui, H.; Barbhuiya, S. Preparation, characterization and thermal properties of dodecanol/cement as novel form-stable composite phase change material. Energy Build. 2013, 66, 697-705. [CrossRef]

7. Powała, K.; Heim, D. Paraffin Permeability of Synthetic Gypsum Binders Modified by Individual Polymers. Latv. J. Phys. Tech. Sci. 2019, 56, 47-56. [CrossRef]

8. Qian, Z.; Shen, H.; Fang, X.; Fan, L.; Zhao, N.; Xu, J. Phase change materials of paraffin in h-BN porous scaffolds with enhanced thermal conductivity and form stability. Energy Build. 2018, 158, 1184-1188. [CrossRef]

9. Ramakrishnan, S.; Wang, X.; Sanjayan, J.; Wilson, J. Thermal performance assessment of phase change material integrated cementitious composites in buildings: Experimental and numerical approach. Appl. Energy 2017, 207, 654-664. [CrossRef]

10. Cellat, K.; Tezcan, F.; Beyhan, B.; Kardaş, G.; Paksoy, H. A comparative study on corrosion behavior of rebar in concrete with fatty acid additive as phase change material. Constr. Build. Mater. 2017, 143, 490-500. [CrossRef]

11. Novais, R.M.; Ascensão, G.; Seabra, M.P.; Labrincha, J.A. Lightweight dense/porous PCM-ceramic tiles for indoor temperature control. Energy Build. 2015, 108, 205-214. [CrossRef]

12. Hajjar, A.; Mehryan, S.A.M.; Ghalambaz, M. Time periodic natural convection heat transfer in a nano-encapsulated phase-change suspension. Int. J. Mech. Sci. 2020, 166, 105243. [CrossRef]

13. Ramakrishnan, S.; Wang, X.; Sanjayan, J.; Wilson, J. Assessing the feasibility of integrating form-stable phase change material composites with cementitious composites and prevention of PCM leakage. Mater. Lett. 2017, 192, 88-91. [CrossRef]

14. Abden, M.J.; Tao, Z.; Pan, Z.; George, L.; Wuhrer, R. Inclusion of methyl stearate/diatomite composite in gypsum board ceiling for building energy conservation. Appl. Energy 2020, 259, 114113. [CrossRef]

15. Yang, H.; Memon, S.; Bao, X.; Cui, H.; Li, D. Design and Preparation of Carbon Based Composite Phase Change Material for Energy Piles. Materials 2017, 10, 391. [CrossRef] [PubMed]

16. Mohseni, E.; Tang, W.; Wang, S. Development of thermal energy storage lightweight structural cementitious composites by means of macro-encapsulated PCM. Constr. Build. Mater. 2019, 225, 182-195. [CrossRef]

17. Sukontasukkul, P.; Uthaichotirat, P.; Sangpet, T.; Sisomphon, K.; Newlands, M.; Siripanichgorn, A.; Chindaprasirt, P. Thermal properties of lightweight concrete incorporating high contents of phase change materials. Constr. Build. Mater. 2019, 207, 431-439. [CrossRef]

18. Ryms, M.; Klugmann-Radziemska, E. Possibilities and benefits of a new method of modifying conventional building materials with phase-change materials (PCMs). Constr. Build. Mater. 2019, 211, 1013-1024. [CrossRef]

19. Ali Memon, S.; Yiu Lo, T.; Shi, X.; Barbhuiya, S.; Cui, H. Preparation, characterization and thermal properties of Lauryl alcohol/Kaolin as novel form-stable composite phase change material for thermal energy storage in buildings. Appl. Therm. Eng. 2013, 59, 336-347. [CrossRef]

20. Marske, F.; Silva, J.M.D.S.E.; Wehrspohn, R.B.; Hahn, T.; Enke, D. Synthesis of monolithic shape-stabilized phase change materials with high mechanical stability via a porogen-assisted in situ sol-gel process. Rsc Adv. 2020, 10, 3072-3083. [CrossRef]

21. Zhang, X.; Kim, Y.; Kim, D.; Liu, M.; Erramuspe, I.B.V.; Kaya, G.B.; Wang, X.; Kim, T.; Via, B.K.; Cho, H. Shape-Stabilized Phase Change Material by a Synthetic/Natural Hybrid Composite Foam with Cell-Wall Pores. Acs Appl. Energy Mater. 2020. [CrossRef]

22. Li, A.; Dong, C.; Dong, W.; Atinafu, D.G.; Gao, H.; Chen, X.; Wang, G. Hierarchical 3D Reduced Graphene Porous-Carbon-Based PCMs for Superior Thermal Energy Storage Performance. ACS Appl. Mater. Interfaces 2018, 10, 32093-32101. [CrossRef] [PubMed]

23. Wen, R.; Zhang, X.; Huang, Z.; Fang, M.; Liu, Y.; Wu, X.; Min, X.; Gao, W.; Huang, S. Preparation and thermal properties of fatty acid/diatomite form-stable composite phase change material for thermal energy storage. Sol. Energy Mater. Sol. Cells 2018, 178, 273-279. [CrossRef]

24. Guo, X.; Huang, Y.; Cao, J. Performance of a thermal energy storage composite by incorporating diatomite stabilized paraffin as phase change material. Energy Build. 2018, 158, 1257-1265. [CrossRef]

25. Rao, Z.; Zhang, G.; Xu, T.; Hong, K. Experimental study on a novel form-stable phase change materials based on diatomite for solar energy storage. Sol. Energy Mater. Sol. Cells 2018, 182, 52-60. [CrossRef]

26. Konuklu, Y.; Ersoy, O.; Gokce, O. Easy and industrially applicable impregnation process for preparation of diatomite-based phase change material nanocomposites for thermal energy storage. Appl. Therm. Eng. 2015, 91, 759-766. [CrossRef]

27. Kastis, D.; Kakali, G.; Tsivilis, S.; Stamatakis, M.G. Properties and hydration of blended cements with calcareous diatomite. Cem. Concr. Res. 2006, 36, 1821-1826. [CrossRef] 
28. Jeong, S.-G.; Jeon, J.; Lee, J.-H.; Kim, S. Optimal preparation of PCM/diatomite composites for enhancing thermal properties. Int. J. Heat Mass Transf. 2013, 62, 711-717. [CrossRef]

29. Qian, T.; Li, J. Octadecane/C-decorated diatomite composite phase change material with enhanced thermal conductivity as aggregate for developing structural-functional integrated cement for thermal energy storage. Energy 2018, 142, 234-249. [CrossRef]

30. Xu, B.; Li, Z. Paraffin/diatomite/multi-wall carbon nanotubes composite phase change material tailor-made for thermal energy storage cement-based composites. Energy 2014, 72, 371-380. [CrossRef]

31. Kuttah, D.; Sato, K. Review on the effect of gypsum content on soil behavior. Transp. Geotech. 2015, 4, 28-37. [CrossRef]

32. Oliver, A. Thermal characterization of gypsum boards with PCM included: Thermal energy storage in buildings through latent heat. Energy Build. 2012, 48, 1-7. [CrossRef]

33. Tang, F.; Su, D.; Tang, Y.; Fang, G. Synthesis and thermal properties of fatty acid eutectics and diatomite composites as shapestabilized phase change materials with enhanced thermal conductivity. Sol. Energy Mater. Sol. Cells 2015, 141, 218-224. [CrossRef]

34. Sarı, A.; Bicer, A.; Al-Sulaiman, F.A.; Karaipekli, A.; Tyagi, V.V. Diatomite/CNTs/PEG composite PCMs with shape-stabilized and improved thermal conductivity: Preparation and thermal energy storage properties. Energy Build. 2018, 164, 166-175. [CrossRef]

35. Xu, G.; Leng, G.; Yang, C.; Qin, Y.; Wu, Y.; Chen, H.; Cong, L.; Ding, Y. Sodium nitrate - Diatomite composite materials for thermal energy storage. Sol. Energy 2017, 146, 494-502. [CrossRef]

36. Cui, H.; Feng, T.; Yang, H.; Bao, X.; Tang, W.; Fu, J. Experimental study of carbon fiber reinforced alkali-activated slag composites with micro-encapsulated PCM for energy storage. Constr. Build. Mater. 2018, 161, 442-451. [CrossRef]

37. Li, C.; Yu, H.; Song, Y.; Wang, M.; Liu, Z. A n-octadecane/hierarchically porous $\mathrm{TiO}_{2}$ form-stable PCM for thermal energy storage. Renew. Energy 2020, 145, 1465-1473. [CrossRef]

38. Zou, D.; Ma, X.; Liu, X.; Zheng, P.; Hu, Y. Thermal performance enhancement of composite phase change materials (PCM) using graphene and carbon nanotubes as additives for the potential application in lithium-ion power battery. Int. J. Heat Mass Transf. 2018, 120, 33-41. [CrossRef]

39. Xu, T.; Li, Y.; Chen, J.; Wu, H.; Zhou, X.; Zhang, Z. Improving thermal management of electronic apparatus with paraffin (PA)/expanded graphite (EG)/graphene (GN) composite material. Appl. Therm. Eng. 2018, 140, 13-22. [CrossRef]

40. Kauffman, K.L.; Culp, J.T.; Goodman, A.; Matranga, C. FT-IR Study of $\mathrm{CO}_{2}$ Adsorption in a Dynamic Copper(II) Benzoate-Pyrazine Host with $\mathrm{CO}_{2}-\mathrm{CO}_{2}$ Interactions in the Adsorbed State. J. Phys. Chem. C 2011, 115, 1857-1866. [CrossRef]

41. Yusan, S.; Korzhynbayeva, K.; Aytas, S.; Tazhibayeva, S.; Musabekov, K. Preparation and investigation of structural properties of magnetic diatomite nanocomposites formed with different iron content. J. Alloy. Compd. 2014, 608, 8-13. [CrossRef]

42. Zhao, D. Adsorption of thorium(IV) on MX-80 bentonite: Effect of $\mathrm{pH}$, ionic strength and temperature. Appl. Clay Sci. 2008, 41, 17-23. [CrossRef]

43. Qian, T.; Li, J.; Min, X.; Guan, W.; Deng, Y.; Ning, L. Enhanced thermal conductivity of PEG/diatomite shape-stabilized phase change materials with Ag nanoparticles for thermal energy storage. J. Mater. Chem. A 2015, 3, 8526-8536. [CrossRef]

44. Yu, H.; Li, C.; Zhang, K.; Tang, Y.; Song, Y.; Wang, M. Preparation and thermophysical performance of diatomite-based composite PCM wallboard for thermal energy storage in buildings. J. Build. Eng. 2020, 32, 101753. [CrossRef]

45. Zhang, P.; Cui, Y.; Zhang, K.; Wu, S.; Chen, D.; Gao, Y. Enhanced thermal storage capacity of paraffin/diatomite composite using oleophobic modification. J. Clean. Prod. 2021, 279, 123211. [CrossRef]

46. Wang, T.; Wang, S.; Geng, L.; Fang, Y. Enhancement on thermal properties of paraffin/calcium carbonate phase change microcapsules with carbon network. Appl. Energy 2016, 179, 601-608. [CrossRef]

47. Cheng, F.; Wen, R.; Zhang, X.; Huang, Z.; Huang, Y.; Fang, M.; Liu, Y.g.; Wu, X.; Min, X. Synthesis and characterization of beeswax-tetradecanol-carbon fiber/expanded perlite form-stable composite phase change material for solar energy storage. Compos. Part A Appl. Sci. Manuf. 2018, 107, 180-188. [CrossRef]

48. Huang, X.; Alva, G.; Liu, L.; Fang, G. Microstructure and thermal properties of cetyl alcohol/high density polyethylene composite phase change materials with carbon fiber as shape-stabilized thermal storage materials. Appl. Energy 2017, 200, 19-27. [CrossRef]

49. Bao, X.; Tian, Y.; Yuan, L.; Cui, H.; Tang, W.; Fung, W.H.; Qi, H. Development of high performance PCM cement composites for passive solar buildings. Energy Build. 2019, 194, 33-45. [CrossRef]

50. Available online: https://www.prweb.com/releases/gypsum-board-industry/report-2014-2016/prweb12155688.htm (accessed on 3 January 2021).

51. Mittal, M.L.; Sharma, C.; Singh, R. Decadal emission estimates of carbon dioxide, sulfur dioxide, and nitric oxide emissions from coal burning in electric power generation plants in India. Environ. Monit. Assess. 2014, 186, 6857. [CrossRef] 